OSMED

e-ISSN 2458-9519
Osmanlı Medeniyeti Araştırmaları Dergisi

Journal of Ottoman Civilization Studies

Cilt 6, Sayı 10, Nisan 2020 \& Vol 6, No 10, April 2020

(C) 2020 Telif Hakkı OSMED'e aittir
DOI: $10.21021 /$ osmed.563346

Geliş Tarihi \& Received: 11.05.2019
Makale Türü: Araştırma Makalesi

Article Types: Research Article

Kabul Tarihi \& Accepted: 09.03.2020

OSMED, 2020, 6(10): 27-63

\title{
Eski Dersim Mebusu Lütfi Fikri Bey’in 1925 Yılında Ankara İstiklal Mahkemesi’nde Yargılanması
}

\author{
The Trial of Lütfi Fikri Bey, Old Parliament Member of Dersim, in the Independence Court
}

\section{Ahmet Ali Gazel*}

$\ddot{O} \mathbf{z}$

II. Abdülhamit, II. Meşrutiyet ve Atatürk dönemlerinde siyasi faaliyette bulunan Lütfi Fikri Bey, genelde her dönemde muhalefette yer almış ve zaman zaman da çeşitli mahkemelerde yargılanmıştır. Lütfi Fikri Bey ilk olarak II. Abdülhamit döneminde mahkeme önüne çıkmıştır. Mısır'da neşredilen Mizan gazetesine yazı yazmayı teklif ettiği gerekçesiyle 1895 yılında 14 ay hapis cezasına çarptırılmıştır. Lütfi Fikri Bey, ikinci olarak Halifeliğin kaldırılmasına karşı çıtığı için 1923 yılında İstanbul'da kurulan İstiklal Mahkemesi'nde yargılanmış ve 27 Aralık 1923 tarihinde İstiklal Mahkemesince beş yıl ağır hapse mahkûm edilmiştir. Ancak 13 Şubat 1924 tarihinde TBMM tarafından çıkarılan 124 sayılı özel bir yasa ile affedilmiştir.

Lütfi Fikri Bey, 1925 yılında ise Ankara İstiklal Mahkemesi'nde yargılanmıştır. Bu seferki suçlama Tarikat-1 Salahiye adlı gizli bir cemiyete üye olmaktır. Lütfi Fikri'nin cemiyetle tam bir bağlantısı tespit edilememiştir. Mahkemede bazı kişilerin adını vermesi ve cemiyet üyelerince 1922 yılında yapılan bir kabine listesinde yer almış olmasından dolayı evinde arama yapılmıştır. Arama sırasında cemiyetle bağlantısını gösterecek bir delil bulunamazken abisi Münci Bey’in yazdığı bir mektup ve 1923 yılına ait günlükleri bulunmuştur. Özellikle günlüğünde Cumhuriyete ve Mustafa Kemal Paşa’ya yönelik bazı ithamlar tespit edilmiştir. Neticede tutuklanarak Ankara İstiklal Mahkemesi’ne sevk edilmiştir. 15 Ağustos 1925 tarihinde karar açıklanmış ve cemiyetle bağlantısına dair bir delil bulunamadığı için Lütfi Fikri Bey beraat etmiştir. Beraat etmesinde cemiyetle bir bağlantısının tespit edilememesi yanında Mustafa Kemal Paşa’nın Lütfi Fikri’nin affına dair mahkeme heyetine yazdığı mektup da etkili olmuştur.

Bu makalede Lütfi Fikri Bey'in Tarikat-1 Salahiye Cemiyeti’ne üye olmaktan dolayı 1925 yılında İstiklal Mahkemesinde yargılanması dönemin gazetelerine dayalı olarak anlatılmıştır.

Anahtar Kelimeler: Lütfi Fikri, İstiklal Mahkemesi, Tarikat-1 Salahiye Cemiyeti

\begin{abstract}
Lütfi Fikri Bey, who carried out political activities during the Second Abdülhamit, Second Constitutional and Atatürk periods, generally took part in opposition in every period and from time to time he was judged in various courts. Lütfi Fikri Bey was first judged in the court in the period of Abdulhamid II. He was sentenced to 14 months in prison in 1895 on the grounds that he had proposed to write for the Mizan newspaper in Egypt. Lütfi Fikri Bey, secondly, was judged in the Independence Court established in Istanbul in 1923 for opposing the abolition of the Caliphate. However, he was forgiven by a special law no. 124 issued on 13 February 1924 by the Turkish Grand National Assembly.

In 1925, Lütfi Fikri Bey was judged in the Ankara Independence Court. This time the accusation was to become a member of a secret society called Tarikat-1 Salahiye. Lütfi Fikri's association with the community could not be determined. His house was searched since some people in the court gave his name and his name was in a list of cabinet members prepared in 1922. While there was no evidence to show his connection to this list during the search, a letter written by his brother Münci and the diaries of 1923 were found. In particular, some accusations against the Republic and Mustafa Kemal Pasha were found in his diary. As a result, he was arrested and sent to Ankara Independence Court. On 15 August 1925, the decision was declared and Lütfi Fikri Bey was acquitted because there was no evidence of his connection to the community. In addition to the lack of a link to the association in the acquittal, Mustafa Kemal Pasha's letter to the court on the forgiveness of Lütfi Fikri was also influential.

In this article, the trial of Lütfi Fikri Bey in the Independence Tribunal in 1925 for being a member of the Order of the Order was described based on the newspapers of the period.
\end{abstract}

Keywords: Lütfi Fikri, the Independence Court, Tarikat-1 Salahiye Society

* (Prof. Dr.); Afyon Kocatepe Üniversitesi, Eğitim Fakültesi, agazel@aku.edu.tr ORCID: orcid.org/0000-0002-7211-6032

Kaynak Gösterme: Gazel, A. A. “Eski Dersim Mebusu Lütfi Fikri Bey’in 1925 Yılında Ankara İstiklal Mahkemesi’nde Yargılanması". Osmanlı Medeniyeti Araştırmaları Dergisi, 6 (2020): 27-63. 


\section{Giriş}

Türk Siyasi hayatının ilginç ve önemli siyasi kişiliklerinden biri de Lütfi Fikri Bey’dir. Osmanlı Devleti'nin son dönemleriyle, Cumhuriyetin ilk yıllarında siyasi faaliyette bulunan Lütfi Fikri Bey ${ }^{1}$, genelde her dönemde muhalefette yer almış ve zaman zaman da çeşitli mahkemelerde yargılanmıştır.

Lütfi Fikri Bey, ilk olarak II. Abdülhamit döneminde mahkeme önüne çıkmıştır. Paris’te hukuk eğitimi alan Lütfi Fikri Bey, 1894'te ülkeye dönmüş ve Misır'da neşredilen Mizan gazetesine yazı yazmayı teklif ettiği gerekçesiyle 1895 yılında 14 ay hapis cezasına çarptırılmıştır. ${ }^{2} 1908$ yılında Dersim mebusu seçilmiş ve İttihat ve Terakki'ye muhalefet ederek 1911 yılında teşkil edilen Mutedil Hürriyetperveran Fırkasının kurucuları arasında yer almıştır. Sert muhalefetinden dolayı 1911 yılında İttihatçılar tarafından tutuklatılmak istenmişse de Lütfi Fikri Bey’in Meclise gitmesi sonucu bu girişim sonuçsuz kalmıştır. Lütfi Fikri Bey’in tutuklanması girişimi nedeniyle Harbiye Nazırı Mahmut Şevket Paşa hakkında verilen gensoru önergesi hayli sert tartışmalara sebep olmuştur. ${ }^{3}$

Lütfi Fikri Bey, gazetecilikle aktif politikayı bir arada yürütmek istemiş ve 29 Nisan 1911 tarihinde Tanzimat adlı hem sorumlu müdürü, hem de başyazarı olduğu bir gazete yayımlamıştır. Ancak İdare-i Örfîye Kararnamesi'nin 6. maddesine dayanılarak "tahdîş-i ezhânı mûcib" (zihinleri karıştırıc1) olduğu ve "şahsiyatla" uğraştığı gerekçesiyle gazetesinin yayını sık sık kesintiye uğramıştır. 1913 yılına kadar neşredilen gazete 15 farklı isim almıştır. ${ }^{4}$ Birinci Dünya Savaşı başlayınca Lütfi Fikri Bey, İsviçre'ye gitmiştir. 15 Ekim 1919 tarihinde ise yurda dönerek ${ }^{5}$ Sabah gazetesinde başyazarlık yapmaya başlamıştır.

Lütfi Fikri'nin Ankara ile arası hiç iyi olmamıştır. İlişkilerin bozulmasına neden olan konulardan ilki, Büyük Millet Meclisi Hükümeti'nin şekli olmuştur. Lütfi Fikri Bey, Millî Mücadele kazanıldıktan sonra İstanbul'a gelen Refet Paşa'nın açıkladığı, Büyük Millet Meclisi Hükûmeti şekline karşı çıkmış ve yasama, yürütme ve yargı kuvvetlerinin bir mecliste toplanması neticesinde kontrolün kaybolduğunu iddia etmiştir. ${ }^{6}$ Lütfi Fikri Bey, bu sisteme karşı çözüm olarak, meşrutiyet ve kuvvetlerin ayrılmasını savunmuştur. Bu konudaki fikirlerini açıklamak için de "Hükümdarlık Karşısında Milliyet Mes'uliyet ve Tefrîk-i Kuvâ Mesâili” adlı bir risale kaleme almıştır. Bu risalesinde, anayasa hukuku açısından böyle bir hükûmetin hiçbir yerde mevcut olmadığını uzun uzadıya açıklamaya çalışmıştır. ${ }^{7}$

\footnotetext{
${ }^{1}$ Lütfi Fikri Bey hakkında geniş bilgi için bkz. Ahmet Ali Gazel, Lütfi Fikri'nin Tanzimat'ı, Konya 2007, s. 9-29; Ali Birinci, "Lutfi Fikri", Diyanet Vakfı İlam Ansiklopedisi, Cilt: 27, Ankara 2003, s. 233-234.

2 Gazel, age., s. 10.

${ }^{3}$ Gensoru hakkında geniş bilgi için bkz. Ahmet Ali Gazel, Osmanlı Meclis-i Mebusan'ında Parlamenter Denetim, Konya 2007, s. 264-269.

${ }^{4}$ Tanzimat gazetesinin aldığı isimler sırasıyla şöyledir: Tanzimat, Zühre, Tazminat, Matbuat, Merih, Tanzimat (ikinci kez), Islahat, Maşrık, Tanzimat (üçüncü kez), Merih (ikinci kez), Matbuat (ikinci kez), Zühre (ikinci kez), Tenbihat, Nevrah, Tesisat, Takdirat, Teşkilat, Teminat, Ifham, Teminat, Tanzimat, (dördüncü kez), Tazminat (ikinci kez).

${ }^{5}$ BOA, Dahiliye Nezâreti Emniyet-i Umumiye Müdüriyeti Seyrü Sefer Kalemi, (DH. EUM. SSM), nu: 38/29.

6 H.Ziya Ülken, Türkiye'de Çağdaş Düşünce Tarihi, İstanbul 1992, s. 355.

7 Lütfi Fikri, Hükümdarlık Karşısında Milliyet Mes'ûliyet ve Tefrîk-i Kuvâ Mesâili, İstanbul 1338; Dursun Ali Akbulut, Saltanat, Hilafet ve Millî Hâkimiyet, Samsun 1994, s. 15.
} 
Lütfi Fikri’nin Ankara ile ilişkilerini gerginleștiren olaylardan birisi de Hilafetin kaldırılması sürecinde yaşanmıştır. 1 Kasım 1922 tarihinde saltanatın kaldırılması üzerine, İsmailiye mezhebi dinî lideri Ağa Han o sırada başvekil olan İsmet Paşa'ya bir mektup yazmış ve mektubunda saltanatın kaldırılmasıyla Halifelik makamının nüfuzu hakkında bazı tereddütlere düştüklerini, bu makamın Müslüman milletlerin güvenine ve saygısına layık bir duruma getirilmesini TBMM'den rica ettiklerini bildirmiştir. ${ }^{8}$ Mektup İsmet Paşa'ya gelmeden İkdam, Tevhid-i Efkâr, Tanin ve İstikbal gazetelerinde yayınlanmıştır. Bu arada Lütfi Fikri Bey, gerginliği arttırıcı bir ariza yayınlamıştır. Tanin gazetesinde yayınladığ 1 "Huzur-1 Hilâfetpenâhiye" başlıklı açık arizasında Lütfi Fikri, "hilafet ecdad-1 uzmamızın azim ve himmetleriyle Türklüğe kazanılmış bir kuvvettir, bir hazine-i maneviyedir" dedikten sonra, Hilafetin kaldırılmasını Türklük için bir intihar olarak değerlendirmiştir. Ayrıca, istifa edeceğini söyleyen Halife Abdülmecit Efendi’ye "ölüm tehlikesi olsa bile mevkiini, asla terk etmemesini" öğütlemiştir. ${ }^{9}$

Lütfi Fikri, Hilafetle ilgili görüşlerinden dolayı Akşam gazetesinde Necmettin Sadak'in da hedefi olmuş ve ağır bir şekilde eleştirilmiştir. ${ }^{10}$ Lütfi Fikri, aynı gazetenin 15 Kasım 1923 tarihli nüshasında, "Lütfi Fikri Bey Meşrutiyet Taraftarı!" şeklindeki bir başlık altında hakkındaki eleştirilere cevap vermiştir. Lütfi Fikri Bey bu yazısında, hilafeti savunduğu kadar, meşrutiyet taraftarı olduğunu da açıklamıştır. ${ }^{11}$ Ayrıca Lütfi Fikri, "Meşrutiyet ve Cumhuriyet" isimli bir eser yazarak meşrutiyet taraftarı olduğunu açıkça dile getirmiştir. ${ }^{12}$

Ağa Han'ın mektubunu yayınlayan gazeteciler ve Lütfi Fikri Bey tutuklanarak İstanbul'da kurulan İstiklal Mahkemesi'ne sevk edilmiştir. Mahkemede, Lütfi Fikri'nin Hıyanet-i Vataniye Kanunu'nun 1. maddesine aykırı yayın yapmaktan dolayı cezalandırılması talep edilmiştir. Yazılarında suç unsuru bulunmadığını belirten Lütfi Fikri ise, "mesele sırf Hıyanet-i Vataniye Kanunu'nun benim davam münasebetiyle bir tefsir-i fiiliye arz edilmiş olmasından ibarettir" iddiasında bulunmuştur. ${ }^{13}$

Mahkeme, 19 Aralık 1923 tarihinde başlamış ve 27 Aralık 1923 tarihinde bitmiştir. Savcı iddianamesinde Lütfi Fikri'nin idamını talep etmiştir. ${ }^{14}$ Neticede 27 Aralık 1923 tarihinde İstiklal Mahkemesince beş yıl ağır hapse mahkûm edilmiştir. ${ }^{15}$ Resmen başvurduğu takdirde affı cihetine gidileceği söylenmişse de Lütfi Fikri "Ben mücrim değilim ki affımı isteyim, isterlerse hakkımdaki hükmü refetsinler!" diyerek bu teklifi reddetmiştir. ${ }^{16}$ Lütfi Fikri, 13 Şubat 1924 tarihinde TBMM tarafindan çıkarılan 124 sayılı özel bir yasa ile affedilmiştir. ${ }^{17}$

8 "Hilafet Meselesine Dair", Tanin, 5 Kanûn-ı evvel 1339, s. 1; Tarık Zafer Tunaya, İslâmcılık Cereyanı, İstanbul 1962, s. 161-162.

${ }^{9}$ Tanin, 10 Teşrin-i sani 1339, s. 1; Tunaya, islâmcılık Cereyanı, s. 162.

10 Necmeddin Sadak, "Hilafet Müessesesi Hakkında", Akşam, 1837, 11 Teşrin-i sani 1339, s. 1.

${ }^{11}$ Lütfi Fikri yazısında şöyle demektedir: "Bize hem hilafeti muhafaza ettirebilecek ve hâkimiyet-i milliyeyi emniyette bulunduracak olan meşrutiyet idaresini tercih ediyorum", Lütfi Fikri, "Lütfi Fikri Bey Meşrutiyet Taraftarı! ", Akşam, 15 Teşrin-i sani 1339, s. 3.

12 Lütfi Fikri, Meşrutiyet ve Cumhuriyet, ìstanbul 1339.

${ }^{13}$ Murat Çulcu, Hilafetin Kaldırılması Sürecinde Cumhuriyetin Ilanı ve Lütfi Fikri Davası, II, İstanbul 1992, s. 166.

14 “Cumhuriyet Müdde-i Umumisi Lütfi Fikri Bey'in İdamını İstiyor”, Tanin, 21 Kanûn-ı evvel 1339, s. 1.

15 "Istiklal Mahkemesinin Illk Kararı", Tanin, 28 Kanûn-ı evvel 1339, s. 1.

${ }^{16}$ Mehmet Reşid, "Meşrutiyet Muhalefetinden Bir Safha Lütfi Fikri'nin Siyasi Mücadeleleri”, Dersim Mebusu Lütfi Fikri Bey'in Günlüğ̈̈, (Yayına Hazırlayan: Yücel Demirel), İstanbul 1991, s. 190.

17 TBMM Zabıt Ceridesi, Devre: 2, İçtima Senesi; 1, C: 5, 802; Çulcu, age., II, s. 271. 
Lütfi Fikri Bey, 1925 yllında Ankara İstiklal Mahkemesi'ne sevk edilmiştir. Bu seferki suçlama, Şark İstiklal Mahkemesi'nin Şeyh Sait İsyanı nedeniyle yaptığı soruşturma sirasında yeniden faaliyete geçtiği tespit edilen ve hakkından soruşturma başlatılan Tarikat-1 Salahiye adlı gizli bir cemiyete üye olmasidır.

Gizli bir cemiyet olduğundan Tarikat-1 Salahiye Cemiyeti'ne dair bugün için net bir bilgi bulunmamaktadır. Cemiyetin, yasal olarak kurulmuş olan İla-yı Vatan Cemiyeti'nin perde arkasındaki örgütü olduğu iddia edilmiştir. Tunaya ve Aybars'a göre cemiyet Sevr Antlaşması'ndan hemen sonra Eylül 1920'de kurulmuştur. ${ }^{18}$ Kurucuları arasında Mehmet Tevfik Baha, Yahya Adnan Paşa, Elif Rıfkı, Celal Bafrevi, Ahmet Refik, Seyit Yusuf Zafari ve Hafız İsmail Hakkı Beyler gibi isimler bulunmaktadır. ${ }^{19}$ Kurucular ağırlıklı olarak Hürriyet ve İtilafçılar ile İla-yı Vatancılardan oluşmuştur. Ancak resmi bir cemiyet olmadığı için üyeleri ve faaliyetleri konusunda net bir bilgi bulunmamaktadır. Zira mahkemede yargılananların önemli bir kısmı, Kiraz Hamdi Paşa'nın haberleri olmadan kendilerini bir deftere yazmalarından dolayı suçlandıklarını beyan etmiş̧lerdir. ${ }^{20}$

Cemiyetin amacı "kurtuluşuna çalıştığı İslam dünyası içinde Osmanlı Devleti'ni de kurtarmaktır". Hilafetçi bir politika da izleyen cemiyet, belirtilen amaçlarına ulaşmak için "İttihatçılarla, Müdafaa-i hukukçularla ve en sonunda Türkiye Cumhuriyeti ve Gazi Mustafa Kemal Paşa" ile mücadeleye girmiştir. İslam dünyası için de ilginç bir plan düşünülmüştür. Şerif Hüseyin tahtından uzaklaştırılarak bir Arap birliği oluşturulacak, böylece halifelik güçlendirilecekti. ${ }^{21}$

Faaliyetlerini 1922 yılında durduran cemiyetin yöneticileri Romanya'ya kaçmıştır. Mahkeme kayıtlarına göre Cemiyet 1925 yılındaki Şeyh Sait İsyanı sırasında yeniden faaliyete geçmiştir. Distol adlı koyunlardaki kelebek hastalıkları için kullanılan ilacı tanıtan gezgin satıcıların bazılarının üzerinde cemiyetle bağlantılarını gösteren mektuplar yakalanmıştır. Yapılan soruşturma neticesinde bu kişilerin Şeyh Sait isyan hareketiyle de ilişkileri olduğu kanaatine varılmıştır. İlk olarak Konya ve çevresinde dolaşan Osman Daver isimli bir kişi tutuklanmış, daha sonra geniş çaplı tutuklamalar yapılmıştır. Tutuklananlar arasında dikkat çekici isimler bulunmaktadır. Bunlardan biri yukarda da belirtildiği gibi İstanbul Barosu Başkanı Lütfi Fikri Bey, diğerleri meşhur tarihçi Ahmet Refik Bey ile Aksekili Ahmet Hamdi Efendi'dir. ${ }^{22}$

Lütfi Fikri'nin cemiyetle tam bir bağlantısı tespit edilememiştir. Mahkemede bazı kişilerin adını vermesi ve cemiyet üyelerince 1922 yılında yapılan bir kabine listesinde yer almış olmasından dolayı 6 Haziran 1925 tarihinde evinde arama yapılmıştır. Arama sırasında cemiyetle bağlantısını gösterecek bir delil bulunamazken, abisi Münci Bey'in yazdığı bir mektup ve 1923 yılına ait günlükleri bulunmuştur. Özellikle günlügünde Cumhuriyete, rejime ve Mustafa Kemal Paşa'ya yönelik bazı ithamlar tespit edilmiştir. Lütfi Fikri Bey evinin aranması sonrası kefaletle serbest bırakılmasına rağmen yukarda belirtilen mektup ve günlüğü yüzünden tutuklanarak İstiklal Mahkemesi'nde yargılanmak üzere 23 Haziran 1923'te Ankara'ya getirilmiş̧tir. Lütfi Fikri'nin mahkemesi Ankara'ya gelmesinden bir ay sonra 26 Temmuz 1925'te başlamıştır.

\footnotetext{
${ }^{18}$ Tarık Zafer Tunaya, "Türk Devrimine Karşı İdeolojik Bir Muhalefet Girişimi: "Tarikat-ı Salâhiyye Cemiyeti” ve Eylemleri”, iü. Iktisat Fakültesi Mecmuası Özel Sayı, Cavit Orhan Tütengil'in Anısına Armağan, İstanbul, 1984, s. 257; Ergün Aybars, istiklal Mahkemeleri, I-II, İzmir 1995, s. 378.

${ }^{19}$ Aybars, age., s. 378.

20 Tunaya, agm., s. 259.

21 Tunaya, agm., s. 260.

22 Tunaya, agm., 262.
} 


\section{I- LÜTFI FIKRİ BEY'IN YARGILANMASI}

Ankara İstiklal Mahkeme Reisi Afyonkarahisar Mebusu Ali Bey’dir (Ali Çetinkaya). Müdde-i Umumi (Savcı) Reşit Galip Bey'dir. Üye olarak ise Ayıntap Mebusu Ali Bey (Ali Kılıç) görev yapmıştır. ${ }^{23}$

Tarikat-1 Salahiye davası yargılamaları 26 Haziran 1925 tarihinde başlamıştır. Davada 68 civarında kişi yargılanmıştır. ${ }^{24}$ En son yargılananlardan biri de Lütfi Fikri Bey olmuştur. Lütfi Fikri Bey'in mahkemesi 26 Temmuz 1925'te başlamıştır. Mahkeme Lütfi Fikri'nin kimlik tespiti ile başlamıştır:

"Reis- Maznuna hitaben, isminiz?

Maznun- Lütfi Fikri.

Reis- Pederiniz?

Maznun- Hüseyin Fikri Paşa.

Reis- Nerelisiniz?

Maznun- Dersim' in Çemişgezek'ten.

Reis- An asıl Dersimlisiniz.

Maznun- Evet Çemişgezekliyim.

Reis- Evli misiniz?

Maznun- Bekârım.

Reis- Kaç yaşındasınız?

Maznun- Elli.

Reis- Hâlen nerede ikamet ediyorsunuz?

Maznun- İstanbul'da efendim.

Reis- Çemişgezek'ten ne vakit ayrıldınız?

Maznun- Oraya pederim ile çocuklukta gittim. Bir de mebusluğu zamanında gitmiş idim. Son gidişim 328'dir (1912).

Reis- Orada akrabanızdan falan kimse var mi?

Maznun- Küçük biraderim var efendim.

Reis- Necidir?

Maznun- Mahalli eşraftandır.

Reis- Büyük biraderiniz de var mı?

Maznun- Efendim. Erkek olarak dört kardeşiz.

Reis- Münci Bey büyüğünüzdür değil mi?

Maznun- Evet efendim.

Reis- Kendisi nerededir?

Maznun- Avrupa'da efendim.

${ }^{23}$ Mahkeme üyeleri hakkında bilgi için bkz. Istiklal Mahkemeleri, I, Ankara 2015, s. 13-29.

${ }^{24}$ Cumhuriyet, 447, 7 Ağustos 1925, s. 1. 
Reis- Ne suretle bulunuyor.

Maznun- Ticaret yapıyor efendim. Evvelce başşehbender idi. Sonra Hollanda'dan başka bir yere yani Brüksel'e tahvil etmek istemişlerdi gitmedi. Orada ticaretle iştigal ediyor.

Reis- Memleketle irtibatını muhafaza ediyor mu?

Maznun- Ne gibi efendim.

Reis- Yani tabiatı falan?

Maznun- Tabii efendim.

Reis- Hakkında takibat-1 kanuniye yapılmış mıdır?

Maznun- Kat'iyen efendim.

Reis- Diğer kardeşleriniz nerededir?

Maznun- Küçük kardeşim Rıfat Bey Anamur Kaymakamıdır. Hâlen İstanbul'da iki ay müddetle mezun bulunuyor.

Reis- İstanbul'da nerede oturuyorsunuz?

Maznun- Gaziköyü'nde Sakarya Sokağı'nda 14 numarada efendim.

Reis- Yalnız misınız?

Maznun- Valide ve hemşiremle beraberim”.

Daha sonra Mahkeme Başkanı Ali Bey, Müdde-i Umumi Reşit Galip Bey’den davanın izah edilmesini istemiştir. Reşit Galip Bey, davanın aylardır devam eden Tarikat-1 Salahiye davasıyla ilgili olduğunu, nitekim Lütfi Fikri'nin evinde yapılan aramada bulunan evrakın da Lütfi Fikri'nin Tarikat-1 Salahiye ile ilişkisinin olduğunu gösterdiğini, onun için de onlarla beraber yargılanmak üzere davaya dâhil edildiğini ifade etmiştir.

Dava konusunun bu şekilde izah edilmesinden sonra Mahkeme Başkanı Ali Bey, Lütfi Fikri’ye Mütareke senelerinde İstanbul'da olup olmadığını sormuştur. Lütfi Fikri de Birinci Dünya Savaş1 sırasında İsviçre'de bulunduğunu, Mütarekeden sonra da İstanbul'a döndüğünü söylemiştir.

Bu cevap sonrası mahkeme başkanı, Lütfi Fikri'nin davaya dâhil edilme sürecini özetlemiştir. Mahkeme Başkanı, Tarikat-ı Salahiye davasından yargılanan bazı kişilerin Lütfi Fikri'nin ismini verdiğini, geçmiş muhalif siyasi hayatı göz önüne alınınca mahkeme heyetinin de bunu dikkate aldığını ve evinde arama yapıldığını, daha sonra kefaletle serbest bırakıldığını, ancak Lütfi Fikri'nin evinde bulunan bazı evrakın Tarikat-1 Salahiye davası ile ilgili olmasa da memleketin mevcut durumu ve geleceği açısından önemli olmasından dolayı Lütfi Fikri'den izahat istenmesine karar verildiğini belirtmiştir. Daha sonra Lütfi Fikri'ye hitaben şöyle devam etmiştir: "Onun için evvel emirde sizden rica ederim ki gayet ciddi ve samimi ve yolunda cevaplar verilsin. Bu sizin lehinize olur. Bugün merkezi Ankara'da olan Cumhuriyet var. Bila-mucib şu veya bu şahsın tecrim edilmesine taraftar değiliz. Ve bundan müstağnidir. Cumhuriyetin halinden ve istikbalinden millet sayesinde o kadar emin bulunuyoruz. Siz Lütfi Fikri Bey öteden beri muhalefetle tanınmış bir şahsiyet olmanız biz hiçbir vakit sizin aleyhinizde davayı hal etmeye vicdanen razı değiliz".

Mahkeme Başkanının bu sözü üzerine Lütfi Fikri Bey de “Ondan çok eminim efendim” diyerek karşılık vermiştir. Daha sonra mahkeme başkanı, Lütfi Fikri'nin Birinci Dünya Savaşı'ndan itibaren siyasi hayatını sorgulamaya başlamış ve savaş sırasında nerede bulunduğunu sormuştur. Lütfi Fikri'nin buna cevabı şöyle olmuştur: "Bendeniz menkub olarak Ayastefanos'ta bulunuyordum. Harb-i umumi başladığı zaman büyük biraderim Hollanda'da Amsterdam başşehbenderi idi. 
Malum-1 aliniz o vakit maişetçe çok sıkıntı çekiliyordu. Bizi oraya davet etti. O vakit ki hükümet birçok muhalifleri bırakmamasına rağmen bendenize namuslu muhalif derler ve takdir ederlerdi. Memleketin aleyhine katiyen bir şey yapmayacağımı bildikleri için Talat Paşa bendenize müsaade etti. Ve gittim daha ucuz bir hayat geçirmek üzere İsviçre'ye gittim. Mütarekeye kadar orada oturdum".

Mahkeme Başkanı, abisi Münci Bey ile beraber mi kaldıklarını sorunca Lütfi Fikri, onun görev mahallinde olduğunu, kendisinin ise validesi ile birlikte İsviçre'de oturduğunu söylemiştir. Lütfi Fikri daha sonra, uzun gayretler ve görüşmeler sonrası İstanbul'a dönmesine müsaade edildiğini, döndükten sonra Sabah gazetesinde başmuharrirlik yaptığın $1^{25}$ ve buradaki yazılarında Kuva-yı Milliye lehinde yazılar yazdığını, hatta Mihran Efendi'nin bundan memnun kalmayarak altı aylık mukavelesi olmasına rağmen iki ay içinde işine son verdiğini söylemiştir. Lütfi Fikri, Sabah'tan ayrıldıktan sonra 1919 seçimlerinde İstanbul mebusluğuna seçildiğini, ancak istifa ettiğini, ${ }^{26}$ istifa sonrası avukatlık yapmaya başladığını hatta İstanbul Barosuna da reis seçildiğini ${ }^{27}$ belirtmiştir.

Lütfi Fikri, daha sonra Damat Ferit Paşa'nın 5 Nisan 1920 tarihinde sadrazam olmasının akabinde Müsalemet İttifakı'nı kurmasından bahsetmiştir. Lütfi Fikri, bu ittifaktan kastının "sulh meselesinde hükümet(i), Anadolu ile teşrik-i mesai etmeye ve Anadolu'nun sözlerini dinlemeye imale ve mecbur etmek" olduğunu ifade etmiştir. Hatta mevcut Maliye Vekili Hasan Bey'in ${ }^{28}$ de idare meclislerin de olduğunu söylemiştir. Lütfi Fikri, Damat Ferit Paşa'nın bu ittifaka sıcak bakmadığını, maksatlarının ne olduğunu artık tarihin söyleyeceğini ifade ettikten sonra ittifakın "Ferit Paşa Kabinesinin istikametinde naçiz bir amil-i müessir olmuş mudur diye bendenize buyrulur ise olmuştur" cevabını vereceğini kaydetmiştir.

Mahkeme Başkanı ne gibi bir etkisinin olduğunu sorunca Lütfi Fikri'nin cevabı şöyle olmuştur: “Anadolu'nun büyük bir ekseriyeti vardır. Anadolusuz bir şey yapılamaz diyorduk. Fazla bir iddiada bulunuyorum. Fakat bendeniz de az çok bu hususta amil oldum ve bu suretle hizmet etmiş oldum. Ondan sonra Ferit Paşa Kabinesi çekildi. O zaman artık büsbütün avukatlığa hasr-1 vakit ettim. Ali Kemal Bey bir çattı. Belki o zamanki gazetelerde manzur-1 aliniz olmuştur. Hatta bir

25 Lütfi Fikri Bey 1 Kasım 1919 tarihinden itibaren Sabah'ta başmuharrirlik yapmaya başlamıştır. Bkz. Lütfi Fikri, "Mesleğim", Sabah, 10761, 1 Teşrin-i sani 1335, s.1.

${ }^{26}$ Lütfi Fikri Bey, 18 Aralık 1919 tarihinde İstanbul Darülfünun konferans salonunda toplanan 164 müntehib-i sani (ikinci seçmenler) tarafından İstanbul mebusu seçilmişse de, yıllarca muhalefet ettiği İttihatçılar tarafından seçtirildiğini düşündüğü için bunu tasvip etmemiş ve istifa etmiştir. Sabah gazetesinin bir tarafında İstanbul mebusu seçildiği yazarken diğer taraftaki başmakalesinde Lütfi Fikri, yıllardan beri mücadele ettiği ittihatçıların listesinden seçilmesini kabul edemeyeceğini belirterek mebusluktan istifa ettiğini açıklamışıı. Lütfi Fikri Bey'in istifasına Dâhiliye Nezareti'nden ve İstanbul basınından sert tepkiler gelmişsir. Bkz. Gazel, Lütfi Fikri'nin Tanzimat'ı, s. 16-17; Lütfi Fikri Bey'in istifa metni için bkz. "istifaname Sureti", Sabah, 10810, 20 Kanun-ı evvel 1335, s. 1; Lütfi Fikri Bey'in bu konudaki açıklamaları için bkz. Lütfi Fikri, "Istifamın Sebebi," Sabah, 10810, 20 Kanun-ı evvel 1335, s. 1; Lütfi Fikri, "Istifam Etrafında," Sabah, 10811, 21 Kanun-ı evvel 1335, s. 1; Lütfi Fikri, 1923 seçimlerinde ise kendi isteğiyle bağımsı aday olmuş, ancak seçilememiştir. Lütfi Fikri, 1923'teki seçim beyannamesini yıllarca mücadele ettiği ittihatçı Hüseyin Cahit'in gazetesi Tanin'de yayınlamışır. Tanin gazetesinde, beyannamenin başına düşülen notta, iktidar ve hamiyetinden şüphe etmedikleri Lütfi Fikri'nin beyannamesini yayınlamakta tereddüt edilmediği açıklanmışır. 25 Haziran 1923 tarihli Tanin gazetesindeki seçim bildirisinde Lütfi Fikri, kendisinin Mecliste bir "emniyet subabı" görevini üstleneceğini yazmıştır. Bkz. Lütfi Fikri, "Muhterem Müntehib-i Sânîlere”, Tanin, 25 Haziran 1339.

${ }^{27}$ Lütfi Fikri Bey, 1920-1925 yılları arasında beş yıl İstanbul Baro Başkanlı̆̆ı yapmıştır. https://www.istanbulbarosu.org.tr 28 Lütfi Fikri Bey'in bahsettiği kişi Türkiye Cumhuriyeti'nin 7. Başbakanı Hasan Saka Bey'dir. Hasan Saka, 3 Mart 1925 ile 13 Temmuz 1926 tarihleri arasında Maliye Vekilliği yapmıştır. 
aralık seyr ü sefain hukuk müşaviri oldum. Nev'ima Anadolu'ya olan hizmetlerimin mükâfatı olarak göstermek idi. Haddi zatında ise 100-110 liralık bir maaş, bendenizin mahiyetinde bulunan bir adam için büyük bir inam ve ihsan olabilirdi. Bunu heyet-i celileniz takdir buyurur. Elhasıl Ali Kemal Bey vesile aradı, bunu buldu ve daima tekrar etti. O müddet zarfinda bendenizin vakit vakit makalelerim neşredildi. Kemal-i iftiharla arz edebilirim ki makalelerimi Anadolu Ajansı, Anadolu'da tamim ediyordu. ${ }^{29} \mathrm{O}$ vaktin koleksiyonları manzur-1 alileri olursa maruzatımın sshhati teyit eder".

Müsalemet İttifakı ile sorgulama devam ederken Mahkeme Başkanı Lütfi Fikri’nin ülkeye dönüşü meselesine geçmiş ve İsviçre'den tam olarak ne zaman döndüğünü sormuştur. O da 15 Ekim 1919 tarihinde döndüğünü söylemiştir. Mahkeme Başkanı nasıl döndüğünü sormuştur. İstanbul'da Hariciye Nezaretinde bu işlerle ilgilenen bir komisyona başvurduğunu ve bu şekilde döndüğünü söylemiş ve şöyle devam etmiştir: "O komisyona bir istida gönderiliyordu. Tahkikat olurdu. İsviçre'den hangi tarikle geçmek isteniyorsa o memleketin konsolosuna müracaat ediliyordu. İtalya'dan geçmek istediğimiz için İtalya Konsoloshanesine müracaat ettik. Ve o kanaldan istidalarımızı gönderdik ve o suretle 4-5 ay kadar beklemek mecburiyetinde kaldık". ${ }^{30}$

Mahkeme Başkanı Ali Bey, Türkiye'ye geldikten sonra Hürriyet ve İtilaf Fırkasındaki eski arkadaşlarıyla görüşüp görüşmediğini sorunca Lütfi Fikri Bey net bir şekilde görüşmediğini söylemiştir: "Kat'iyen alakadar olmadım efendim. Bendeniz o fırka hakkında son notamı vermiştim ki 1329 (1912-1913) senesinde İttihat ve Terakki ile uğraștı̆ı̆ımı vakit Abdurrahman Şeref Bey merhumun meşhur bir sözü vardı. Bir cemm-i gafîr toplanmak lazım geliyordu. Artık o kadar arkadaşları seçmeye ihtiyaç yok idi. Bir blok yaptık. Ondan sonra bendenizi birkaç ay geçmeden İttihat ve Terakki'den tebaüd ettiren esbab ve avamil ne ise bu firkadan da tebaüdüme yegâne sebep o oldu. Bundan sonra semtine uğramadım. Hatta Meşrutiyet Paşası diye bir makale yazmıştım. Kâmil Paşa bizim bir nevi bayrağımız idi. Kâmil Paşa deyince memleketteki çeşmeden su yerine bal akar diyor ve böyle zan ediyorduk. Bu hususta arz ettiğim gibi makale yazmış ve biz Kâmil Paşa, şu paşa, bu paşa için değil meşrutiyet için çalışıyoruz demiştim. ${ }^{31} \mathrm{O}$ günden beri Hürriyet ve İtilaf bendenize yabancı kalmıştır. Alakam yoktur".

Mahkeme Başkanı "Hiç alakadar olmadın mı?" diyerek tekrar sorunca Lütfi Fikri, "Kat'iyen efendim, hatta hiçbir cemiyetle alakadar olmadım" diyerek mukabele etmiştir. Ali Bey, İla-yı

${ }^{29} 1923$ yılındaki yargılanması sırasında Lütfi Fikri'nin avukatı Kuddusi Bey, Lütfi Fikri Bey'in Ali Kemal’e karşı 2 Ağustos 1921 tarihinde Illeri gazetesinde yazdığı yazıyı (Lütfi Fikri, “Ne Yapmalıyız?”, Illeri, 1261, 2 Ağustos 1337, s. 2) okuduktan sonra Lütfi Fikri'nin bu yazılarının Anadolu Ajansıyla her tarafa neşr ve ilan edildiğini söylemiştir. Çulcu, age., II, s. 207208; Aynı mahkemede Lütfi Fikri Bey de 21 Ağustos 1921 tarihinde Ali Kemal hakkındaki yazdığı makaleyi okuduktan sonra Mahkeme Başkanına "Bunu yazana hain-i vatan demek, gayretullaha dokunur beyefendi" demiştir. Çulcu, age., II, s. 236.

30 Lütfi Fikri İstanbul'a döndükten sonra Sabah'a verdiği röportajda İstanbul'a ancak dört ayda gelebildiğini söylemiştir. "Lütfi Fikri Bey", Sabah, 10747, 18 Teşrin-i evvel 1335, s. 1.

${ }^{31} 1913$ yılında Hürriyet ve İtilaftan ayrılan ve Kâmil Paşa'dan da ümidini kesen Lütfi Fikri, 2 Ocak 1913 tarihinde yazdığı makalede o tarihten sonra şahıs veya fırka adına hareket etmeyeceğini ve meşrutiyet için çalışacağını ilan ediyordu. Bkz. Lütfi Fikri, "Meşrutiyet Paşa İçin!..", Tazminat, 405, 20 Kanun-ı evvel 1328, s. 1; Günlüğünde de "Her halde ben iki taraftan da uzağım. Ne İsmail Gümülcineli ile olabilirim, ne berikilerle. Onlar iktidara gelseler belki beni nefy edeceklerdi. "Kamil Paşa'ya itiraz ettin, Mevkini sarstın" diyeceklerdi. ... Belki İttihatçılardan bana fayda olur da bu heriflerden olmaz" diyerek Hürriyet ve İtilafçılara olan tepkisini dile getirmiştir. Lütfi Fikri Bey'in Günlüğü, s. 109. 
Vatan' $1^{32}$ sorunca Lütfi Fikri, "Kat'iyen efendim. Hatta bu isimleri son zamanlarda işitmiştim" demiştir.

Mahkeme Başkanı daha sonra tekrar Müsalemet İttifakı meselesine dönmüş ve ittifakı kimlerle kurduğunu sormuştur. Lütfi Fikri bu ittifak1 kurmadan önce gazetelerde bir beyanname yayımlayarak ${ }^{33}$ mevcut durumda birlik ve beraberlik içinde olmanın gerekli olduğunu belirttikten sonra bu şekilde düşünenlerin mektupla kendisine başvurmasını istediğini, yüzün üzerinde mektup aldığını ve neticede Hurşit Paşa, eski Maliye Nazırı Said Bey, Amasya Mebusu esbakı İsmail Hakkı Paşa, muharrirlerden Asaf Muammer ve hâlen Maliye Vekili bulunan Hasan Bey'in de içinde bulunduğu on kişiyle ittifakı kurduğunu söylemiştir. ${ }^{34}$

Mahkeme Başkanı bu ittifakın firka şeklinde mi olduğunu sorunca Lütfi Fikri "Hayır efendim Lig mahiyetinde idi. Muayyen bir maksat ve muayyen bir iş için uğraşacaktım" diye karşılık vermiştir. $\mathrm{Bu}$ cevap sonrası Mahkeme Başkanı "Yani Anadolu İstanbul'a mı tabi olsun istiyordunuz?" diye bir soru sorunca Lütfi Fikri şöyle devam etmiştir: "Malum-1 aliniz bu gibi şeylerde vekayi inkişaf ettikçe fikir ve emel de inkişaf eder. Bizim iddiamız daima ve bilvasita göstermek istiyorduk ki İstanbul'un yapacağ 1 sulh, sulh değildir. Milletin ekseriyet-i azimesi Anadolu'dadır ve Kuva-yı Milliye ile beraberdir. Binaenaleyh hükümet sulhu Anadolu ile beraber yapmalıdır. Anadolu'yu ihmal etmemelidir şeklinde idi. Ve nokta-i nazarımız da bu idi. Ahval ve zamanın müsaadesi nispetinde bunu takip ediyorduk. Birkaç defa Ferit Paşa ile görüşmek istedim. Bir defasinda kabul etti. Kendisine anlattım".

Daha sonra Başkan, Vahdettin ile doğrudan veya dolaylı olarak görüşüp görüşmediğini sormuştur. Lütfi Fikri Bey, hiçbir şekilde temasının olmadığını söylemiştir. Daha sonra Lütfi Fikri, Damat Ferit Paşa ile görüşme sebebini açıklamışıı: "Bendeniz Ferit Paşa'ya Anadolu'ya geçmek için müsaade talebi zımnında gitmiştim. Anadolu'ya geçmek istiyordum. O vakit bırakmıyorlardı. Hatta o zaman gazeteler yazmışlardı. Lütfi Fikri Anadolu'ya gidiyormuş, gidecek imiş diyorlardı".

Mahkeme Başkanı "Anadolu'ya niçin gidecektiniz?" diye devam edince Lütfi Fikri Bey, "Ahvale daha yakından vakıf olmak için" şeklinde cevap vermiştir. Lütfi Fikri, Mahkeme Başkanının "Ferit Paşa'nın ne gibi müsaadesiyle gelecektiniz?" şeklindeki sorusuna ise şöyle cevap vermiştir: "Ferit Paşa izin veremem dedi. Buna biz karışmayız. Sefarethanelerden birisinden izin alınız dedi. Yoksa Vahdettin ile kat'iyen alakam yoktur. Sulh ve Müsalemet İttifakı için doğrudan doğruya Ferit Paşa ile temas ettik. Bu hususta Hasan Beyefendi izahat-i lazımeyi verirler".

\footnotetext{
32 Ila-yı Vatan Cemiyeti, 19 Kasım 1919 tarihinde kurulmuştur. İstanbul Hükümetini destekleyici olarak kurulan cemiyet, Hürriyet ve İtilaf Fırkası iç̧indeki karışıklıktan yararlanarak teşkil edilmiştir. Cemiyet Milli Mücadele karşıtı ve İngiliz yanlısı bir siyaset izlemiştir. Her ne kadar görünürdeki Reisi Yahya Adnan Paşa olsa da gerçek reisin Kiraz Hamdi Paşa olduğu iddia edilmiştir. Kiraz Hamdi Paşa üye sayısını çok gösterebilmek için kayıt defterine ünlü birçok kişinin ismini yazmıştır. Ki bu isimler 1925'te Ila-yı Vatan'ın gizli örgütü olduğu iddia edilen Tarikat-ı Salahiye davasında yargılanacaklardır. Illa-yı Vatan Cemiyeti için bkz. Tarık Zafer Tunaya, Türkiye'de Siyasal Partiler, II, İstanbul 1999, s. 505-510.

${ }^{33}$ Lütfi Fikri'nin Müsalemet İttifakı öncesi yayımladığı beyanname için bkz. "Enzâr-ı Millete", Alemdar, 2 Haziran 1336, s. 2; Ileri, 2 Haziran 1336, s. 3; ikdam, 2 Haziran 1336, s 1.

${ }^{34}$ Lütfi Fikri Bey'in 1920 yılında teşkil ettiği Müsalemet Itttifakı hakkında geniş bilgi için bkz. Ahmet Ali Gazel, "Lütfi Fikri Bey'in Ankara ile İstanbul'u Uzlaştırmak İddiasıyla 1920 Yılında Kurduğu Bir Ittifak: Müsalemet ittifakı". Mustafa Kemal Üniversitesi Sosyal Bilimler Enstitüsü Dergisi, 16/44, 2019, 14-44.
} 
Müsalemet İttifakı'na dair sorular bitince Mahkeme Başkanı Lütfi Fikri’ye tekrar Hürriyet ve İtilaf Fırkası'ndaki arkadaşlarıyla münasebetinin devam edip etmediğini sormuştur. Lütfi Fikri buna ne evet ne de hayır diyebileceğini belirttikten sonra şöyle devam etmiştir: "Mesela köprüde birisine rast gelmişim ve selam vermişim. Münasebet bu kabildendir. Fakat öyle merkezlerine gitmek merkezlerinde kendileriyle temas etmek gibi bir münasebette bulunmadım. Ve kat'iyen düşünmedim. Hatırıma bile getirmedim. Onlara nispeten bana daha yakın cemiyetler var idi. Bendeniz oraya gidebilirdim. Mesela Sulh ve Müsalemet Cemiyeti vardı ki orada pek sevgili ve kıymetli arkadaşlarım vardı. Oraya girebilirdim. Fakat girmedim. Bendenizin kanaatim ahval ve zamanı nazar-1 dikkate alarak firka teşkil etmemek merkezinde idi”.

Daha sonra Mahkeme Başkanı yargılananlardan birinin evrakı arasında İla-yı Vatan ile İngiliz Muhipler Cemiyetleri tarafından 1922 yılında hazırlanan bir kabine listesi bulduklarını, bu listede Lütfi Fikri'nin dördüncü sırada yer aldığını, bu listeden yer almasının onlarla beraber çalıştığına delil olabileceğini belirttikten sonra bu konuda Lütfi Fikri'nin görüşünü sormuştur: "338 senesinde İla-yı Vatan Cemiyeti ve zan ederim kısmen İngiliz Muhipler Cemiyeti tarafından tertip edilmiş bir liste gördük. Bu liste maznunlardan birisinin evrakı içinde bulunmuştu. O listede zat-1 alinizi de dördüncü olarak gösteriyorlar. Mezkûr listede bir kabine teşkil etmek esasına binaen yapılmıştır. Bu listede mesela Prens Sabahattin, Mustafa Sabri, Reşit Bey, Kiraz Hamdi ve daha böyle 15-20 isim var. Bu liste bize bir fikir veriyor ki sizin de onlarla beraber çalışabilmekliğiniz kabil-i husuldür ve imkân dâhilindedir. Anadolu mücadelesine taraftarlık yaptığınıza ve neşriyatta bulunduğunuza nazaran bu listenin tasavvur ve tertibatını sizin mütalaanız nokta-i nazarından nasıl buluyorsunuz?".

Lütfi Fikri Bey, haberi olmadan yapılan bir listeden suçlanamayacağını savunmuştur: "Efendim! Heyet-i Vükela listesi buyurdunuz da, daha evvelki bir takım şeyler hatırıma geldi. Bendeniz mebus iken ihtimal ki zat-1 alileri de görmüştür. Tanin birçok mektuplar yazmış ve heyet-i vükela kimlerden mürekkep olmalıdır tarzında bir sual açmıştı. Birçok kimseler buna cevap yazdılar. $\mathrm{Bu}$ cevapların pek çoğunda bendenizin de ismi var idi. ${ }^{35}$ Hatta o vakit Tanin gazetesi memlekette henüz heyet-i vekile tertip etmek için tebellür etmiş bir kanaat yoktur. Çünkü Lütfi Fikri ile fikren taban tabana zıt olanlar aynı listeye ithal ediliyor demişti. Bu da onun gibi benim gıyabımda yapılmıştır. O zatlar benim eski marufiyetimi nazar-1 dikkate alarak böyle bir şey tertip etmişler ve beni de gıyabımda o listeye ithal etmişlerse bendeniz buna ne diyebilirim efendim".

Daha sonra yargılama şöyle devam etmiştir:

"Reis- Listeden bazılarını okuyayım. Münasebetlerine dikkat buyrulsun. Prens Sabahattin, Reşit Bey, Muhtar Bey, Lütfi Fikri Bey, Ali Kemal Bey, Sait Molla, Cemil Paşa, Mustafa Sabri Efendi, İsmail Sitkı Bey, Seyyit Abdülkadirzadeler, Rıza Tevfik Bey, Gümülcineli İsmail Bey, Ahmet Refik Bey, Hüseyin Remzi Paşa, Hamdi Paşa, Ferit Paşa, Kâmil Paşazade Şevket Bey vesaire?

\footnotetext{
35 İkinci Meşrutiyet döneminde Sadrazam İbrahim Hakkı Paşa her ne kadar İttihat ve Terakki'nin desteği ile iktidara gelse de İttihatçılarla sık sık görüş ayrılığına düşmüş ve bu nedenle basında zaman zaman hükümette kriz olduğu haberleri çıkmıştır. İttihatçı Hüseyin Cahit Bey de Tanin'de liyakatsiz bazı nazırların değişmesi gerektiğini savunmuştur. Ayrıca Hüseyin Cahit Bey, 1910 yılı sonlarında konuyu okuyucularına da taşıyarak okuyucuların kimleri nazır görmek istediklerini sormuştur. Bu konuda Tanin'e yüze yakın mektup gelmiştir. Bu mektuplarda birçok isim zikredilmiştir. Bunlardan biri de Lütfi Fikri'dir. Bkz. Tanin, 21-22 Teşrin-i sani 1326.
} 
Maznun (Lütfi Fikri)- Efendim! Bunlar bendenizin ilk muhalefetimden kalmış intibaat ve ihtisasata nazaran tertip edilmiş bir liste olsa gerektir.

Reis- Şunu demek istiyorum ki bunların içerisinde mezc ve terkip edebilmek sizin kanaat ve içtihadınızca İstanbul siyaseti nokta-i nazarından mahzur teşkil edecek derecededir?

Lütfi Fikri- 338'de (1922) yapmışlar efendim.

Reis- Bunu bir cemiyet tertip etmiştir. Ve bu cemiyet Yahya Adnan Paşa'nın riyaseti altındadır ve bu doğrudan doğruya Tarikat-1 Salahiye'yi arkasında saklayan bir cemiyettir. Oradan emir ve talimat alır ve Vahdettin tarafindan idare olunur. Letafet Apartmanı da merkezidir. Ve bu vesaik-i tahririye ile müsbettir. Buyurduğunuz mütalaata rağmen calib-i nazar-1 dikkat görüldü. Bu listedeki tertibi nasıl görüyorsunuz?

Lütfi Fikri- Efendim malum-1 alilerinizdir ki bir maznun kendi fiilinden muhakeme edilir. Ve ancak kendinden sadır olan bir fiili müdafaa edebilir. Bendenizi muhalif bildikleri için bu listeye ithal etmişler. Fakat yegâne böyle teklif vaki olmuş ve ne de kabul etmişim. Arz ettiğim gibi bendenizde bir iktidar görerek gıyabımda böyle bir liste tertip edilirse bendeniz buna ne suretle cevap verebilirim. Mesela listede Prens Sabahattin Bey de var. Hâlbuki Sabahattin Bey Avrupa'da idi. Reşit Bey'den bahsediliyor. O da İsviçre'de idi. Bendeniz öyle zan ediyorum ki: O zamana kadar tecrübe edilmiş ve az çok muhalif geçinmiş olanları hatırlarına getirmişler ve bu suretle bir liste tanzim etmişler olsa gerek. Şimdi bendeniz kendimi ne türlü müdafaa edeyim. Bu zevat ile teşrik-i mesai için teklif vaki olsa idi onlarla teşrik-i mesai etmeyeceğimi heyet-i aliyenize ne suretle arz ve izah edebilirim. Kendi karihalarından çıkmış olan bir şeye bendeniz şu veya bu şekilde nasıl cevap verebilirim. Deminde bilmünasebe arz etmiştim Tanin'e birçok kariler listeler göndermişlerdi. O karilerden bazıları bugün maazallah bir fiil ile maznun olarak tasavvur-1 alinize gelse idi, onun da evrakı arasında vaktiyle yapmış olduğu liste arasında Lütfi Fikri'nin ismi çıkmış olsa idi bendenizin mücrim mi olmaklığım lazım gelirdi. Şimdi Reis Beyefendi bu vaziyet karşısında kendimi nasıl müdafaa edeyim. Herhalde eskiden muhalif tanınmış olmaklığım bunlara bu fikri vermiş efendim." ${ }^{36}$

Kabine listesi meselesi bittikten sonra Mahkeme Başkanı, Lütfi Fikri Bey'e 1919 yılında mebusluktan istifa etme nedenini sormuştur: Lütfi Fikri'nin cevabı şöyle olmuştur: "Bilmem hatır1 alilerine gelir mi efendim. $\mathrm{O}$ vakit birçok listeler yapıldı. Harpten sonra milletin sükûna ihtiyacı var idi. Fırkalar bulunsun, fakat tefrika olmasın umumen birleşilsin isteniliyordu. Tertip edilen listede Prens Sabahattin'in de ismi var idi. Kezalik Reşit Bey'in gazetelerdeki listelerde de ismi var idi. Bendenizin de ismim var idi. Nihayet intihap günü geldi. İntihap gününe kadar muhtelif firkalardan 10-12 mebus çıkıyordu ki bunların üzerinde az çok aşağı yukarı ittifak edilmiş̧ bulunuyordu. Ve usulünde bir şey idi. Ve bu zatlardan mürekkep bir kabine vücuda gelse idi, iyi idi. Çünkü gazetelerde bu zatlar hakkında propagandalar yapılmış ve firkalar bunların üzerinde ittifak etmiş idi. Ve ortaya kimsenin nazar-1 istigrabını tevlit edecek bir şey yok idi. Fakat maatteessüf o gece haber aldık ki ne İttihat ve Terakki ve ne de diğer firkalarca namzed gösterilmeyen, hatta ismi bile geçmeyen ve haklarında propaganda yapılmayan Numan Efendi ile Mahmut Kâmil Efendi isminde iki zat azim bir ekseriyetle mebus intihap edildiler. Bu hal bendenizin intihabın ciddiyeti hakkındaki kanaatimi sarstı. Bunun üzerine dedim ki, bunu yarın herkes okuyacak, bir adam hakkında propaganda yapılmadan ve hiç ismi mevzu-1 bahs olmadan

${ }^{36}$ Hâkimiyet-i Milliye, 1485, 28 Temmuz 1341, s. 1-2. 
mebus olursa ve memleketçe tanınmamış olursa ve bu da azim bir ekseriyetle intihap olunursa intihabın ciddiyeti hakkında bir kanaat hâsıl etmenin imkânı olamayacağına karar verdim. Ve esasen efkâr-1 umumiyede bunu böyle telakki edecek idi. Bunu kabul ettikten sonra serbest bir intihap karşısında olmadığımızı ve işin içinde bir komite parmağı olduğunu ve müntehiblere icray1 tesir eden komitemsi bir kuvvetin mevcut olduğuna kanaat getirdim. Ve böyle komite elinde olan müntehiblerin verdiği reye itimadım yoktur dedim ve mebusluğu kabul etmedim. Hatta ertesi günü gazetede de yazdım. Bana kimler reyini verdi ise isimlerini bildirsinler göreyim. Kanaat getiriyim ve bana rey veren müntehibler beni takdir ederek memleketin mebusluğuna layık görmüş insanlar midır ve bunu anlayayım dedim. Ve bu suretle mebusluğu kabul edebileceği mi de yazdım".

Daha sonra Lütfi Fikri Bey'in 1919 yılında mebusluktan istifasıyla ilgili yargılama şöyle devam etmiştir:

"Reis- Müntehib-i sani olarak kimleri istiyordunuz?

Lütfi Fikri- Mesela bendeniz istiyordum ki mümkün mertebe müstakil-ül-efkâr kalmış ve İttihat ve Terakki'nin o vakte kadar devamı olan mesavi-i ahvaline iştirak etmemiş kimseler olsun.

Reis- Onları intihap edenleri de onlardan $\mathrm{m}$ zan ediyordunuz?

Lütfi Fikri- Mademki 250-300 müntehib-i sani böyle ismi bir gün bile olsun mevzu-1 bahs olmamış adamlara rey veriyorlar ve o adamları da İttihat ve Terakki tutuyor diye bir şayia vardı, artık İttihat ve Terakki'nin elinde bir oyuncak karşısındayız dedim ve bunu bir şeref ve haysiyet meselesi telakki ettim. Belki yanlış veya doğru idi. Fakat bir şeref meselesi telakki ettim ve mebusluğu kabul etmedim.

Reis- Hâlbuki o surada İttihat ve Terakki tamamen inhilal etmiş bir vaziyette bulunuyordu. Çünkü müdiran-1 umuru firar etmiş, bir kısm-1 mühimmi tevkif edilmiş, bir kısm-1 mühimmi de Malta'ya sevk olunmuştu. Şimdi tasavvur ettiğiniz gibi tezahür eden hangi bir neticeyi İttihat ve Terakki'ye atf etmek -nasıl ki Ali Kemal tasavvur ediyordu- o demektir.

Lütfi Fikri- Hakk-1 aliniz var efendim. Fakat hiç isimleri geçmeyen Kâmil Efendi ile Numan Efendi iki yüz üç yüz rey ile mebus olsunlar.

Reis- İyi ya. Numan Efendi, amale sınıfinı temsil ediyor. Siz onu millet nokta-i nazarından ne hakla mebusluğa layık görmüyorsunuz?

Lütfi Fikri- O mesele değil, müntehib-i sanilerle bu zevat arasında hiçbir rabita ve temas yoktu. Malum-1 aliniz intihabat az çok aleni ve malum olur. Sonra İttihat ve Terakki'nin kalmış, nefyedilmiş zevatı birçok namlar altında birleşmişlerdi ve hep ayrı ayrı gazetelere beyanatta bulundular. Ve bütün bu hizipler listelerini resmen tebliğ ettiler. Bu hiziplerde İttihat ve Terakki de dâhildi diğerleri de dâhildi. Numan Usta'nın Kâmil Efendi'nin isimleri yoktu. Binaenaleyh bize iyi bir sürpriz olmuştur.

Reis- Gördünüz ki 1335 (1920) meclisinde doğrudan doğruya milli bir blok tesis etmiş ve Misak1 Milliyi vücuda getirmiştir. Ne İttihat ve Terakki ve ne de diğer bir firkanın program veya ihtarı vukua gelmiştir. Daha doğrusu bir yangın vardı. Yangın nereden çıktı diye sebep araştırmadan o yangını söndürmeye kalktılar. $\mathrm{O}$ zaman da herkes hamiyet-i vatanın icabatını yapmak istedi. Hâlbuki zat-ı aliniz İttihat ve Terakki müsebbebdir. İttihat ve Terakki'den olmamalıdır diyorsunuz. 
Lütfi Fikri- İttihat ve Terakki'yi kastettim. Yalnız bir gün zarfinda hiç ismi mevzu-1 bahs olmayan iki kişinin hafi bir propaganda ile mebusluklarının temin edilmiş olduğunu görünce bendeniz bunda bir komite parmağı hissettim. Bu parmak İttihat ve Terakki olabilir yahut başkası olabilir. Herhalde bunlar bendenizin bir demokraside vücudunu arzu ettiğim şekil ve suretlerin başka nevi idi.

Reis- Bir defa o meclisi açtırmaya bir kuvvet icbar etmiştir. Anadolu kuvveti, Anadolu hareketi sonra zan ederim ki -pek günahınıza girmeyelim- siz o meclisin akıbetini pek yakından biliyordunuz.

Lütfi Fikri- Kat'iyen bilmiyordum, o muameleyi bendeniz hatıramda bir cinnet olarak telakki etmişimdir.

Reis- Hangisini?

Lütfi Fikri- İstanbul Meclis-i Mebusan'1n kapatılmasını.

Reis- Millet burada mevcudiyetini göstererek 23 Nisan'da Birinci Büyük Millet Meclisi'ni açmıştır. O zaman o büyük efendiniz kasd-1 hainanesini tatbikte büyük bir hata yaptığını anladı.

Lütfi Fikri- Bendeniz daha evvel anladım.

Reis- Olabilir. Netice ile zat-1 alinizin serdettiğiniz iddianız arasında büyük bir fark vardır. Muhakeme edilirse makuliyet de yoktur. Onu siz hususi sebepler tahtında reddetmişsinizdir. Ve bunun için istifa ettiniz.

Lütfi Fikri- Kat'iyen efendim. Malum olan hayatım prensiplerim hakkında bir fikir verir.

Reis- Prensipleriniz meydandadır. Bütün prensipleriniz memleketin selamet ve istikbali nokta-i nazarından daima fenalıkla neticelenmiştir.

Lütfi Fikri- Bendenizin inhilal etmiş teşebbüsüm yoktur. 338 senesinde İstanbul cephesinde Kuva-yı Milliyenin en car müdafii idim”.

Daha sonra konu Lütfi Fikri’nin İkinci Meşrutiyet döneminde İttihat ve Terakki'ye olan muhalefetine gelmiştir:

'Reis- 324'den (1908) itibaren muhalefete başladınız değil mi?

Lütfi Fikri- Evet efendim.

Reis- 335-336'ya (1919-1920) kadar bu suretle devam ettiniz. Ondan sonra da memleket hesabına çalıştığınızı söylüyorsunuz, hâlbuki bittekrar muhalefet mevkiine geçtiniz.

Lütfi Fikri- Muhalefeti, muhalefet olmak için yapmadım. Beğenmediğim için yaptım.

Reis- Rasim Avni Hoca da öyle söylüyor. 31 Mart Vakası'nı bir irtica değil bir vaka-i hayriye diye müdafaa ediyor.

Lütfi Fikri- Ben öyle değilim efendim.

Reis- Arnavutlarla, Rumlarla, Bulgarlarla birleştiniz.

Lütfi Fikri- Bendeniz mi? 
Reis- Evet zat-1 aliniz. Gazetelerinizin koleksiyonları meydandadır. İsterseniz şimdi göstereyim. Memleketin mezarını kazdınız. Bütün Arnavutların makalelerini sizin gazeteniz yazmış ve kasıtlarını müdafaa etmiş̧tir. Priştine Mebusu Hasan'ın en fena makaleleri sizin gazetenizdedir. ${ }^{37}$

Lütfi Fikri- Muhalefette bu gibi şeyler aranmıyor. Biz o zaman İttihat ve Terakki'nin muhalifi olarak bulunuyorduk. Vicdan-1 alinize müracaat ederim. Siz böyle muhalif bir vaziyette olsanız ve elinizde bir gazeteniz olsa her şeyi bu kadar ince arayabilir misiniz? Buna maddeten imkân yoktur".

Bu cevap sonrası Mahkeme Başkanı "Tamam çok güzel söylüyorsunuz. Memleket birçok felaket neticesinde parçalandıktan sonra düşmanlarımızın da tasdik ettiği vecihle bir cumhuriyet-i idareye nail olmuş ve bütün manasıyla kurtulmuştur. $\mathrm{Bu}$ hareket kapitülasyonları falan hep silip süpürmüştür. İstiklalini ve tamamiyet-i mülkiyesini temin etmiş̧ir. Fakat siz bugün onu da beğenmezsiniz" diyerek konuyu Lütfi Fikri’nin Cumhuriyete olan düşmanlığına getirmiştir.

Lütfi Fikri Bey bu fikre nereden ulaştıklarını sorunca Başkan, Lütfi Fikri’nin 1923 yılına ait hatıratını gündeme getirmiştir: "Bütün kanaatlerinizi tespit etmişizdir. Bugünkü vaziyeti vücuda getiren anasır ve avamili en fena zihniyetle öldürmek istiyorsunuz. Bunu ispat edebilmek için zihniyetinizi gösteren hatıratınıza geliyoruz. Gerçi 339'da (1923) yazmıssınız. Fakat memleket kurtulduğu zaman dahi Lütfi Fikri'nin memleket hakkındaki düşüncelerini millet bilsin”.

Lütfi Fikri buna, "Hangi tarihte yazıldığını bilmiyorum. Fakat 1. İstiklal Mahkemesi'nin müddei umumilik mevkiini işgal eden Vasıf Beyefendi buyurdular ki dimağa, fikre karşı mücadele açılmamıştır. Fikirler mukaddestir, muhteremdir. Onlarla mücadelemiz yoktur. Yalnız bir cürüm şeklinde tecelli edene karşıdır, demişlerdi. ${ }^{38}$ Buyurduğunuz hatıraların mesuliyet-i maneviyesini kabule hazırım çünkü yazmışımdır. Bunlar benim eserlerimdir. Fakat şu elinizdeki hatıralar ilk defa polis marifetiyle güneş görmüştür. Benim harim-i dimağımdır. Bu benim kafamdır. Yani kafamdaki tefekkürat ile o sahifelere geçmiş sözler arasında hiçbir fark yoktur" şeklinde mukabele etmiştir.

Mahkeme Başkanı "Okuyalım da millet görsün ve hakikati anlasın" deyince Lütfi Fikri, "Hay hay efendim, arzu buyurursanız millet de görsün öğrensin" diye karşılık vermiştir. Bu arada Reşit Galip Bey araya girerek "Bir heyet-i fesadiyenin faal bir uzvu bulunduğunuz iddiasiyla burada bulunmaktasınız. Dimağımda bulunan şeyler için mesul sorulmak olmaz diyemezsiniz" demiştir.

Sonrasında yargılama şöyle devam etmiştir:

"Lütfi Fikri- Ben demek istiyorum ki bu defterlerdeki hatıralarım polis marifetiyle güneş görmüştür.

Reis- İşte o harim-i dimağınızın eserlerini firsat buldukça millete daima bir zehir gibi saçacaksınız?

Lütfi Fikri- Kat'iyen efendim. Estağfurullah saçtığım vakit cürüm olur.

\footnotetext{
37 Priştine Mebusu Hasan Bey'in Lütfi Fikri'nin gazetesinde 15 makalesi yayımlanmıştır. Hatta Hasan Bey Zühre isimli bir gazete imtiyazı alarak devamlı gazetesi kapatılan Lütfi Fikri'ye vermiştir. Gazel, Lütfi Fikri'nin Tanzimat'ı, s. 61-62.

381923 ylında Hilafeti ve meşrutiyeti savunmasından dolayı yargılanırken Müdde-i Umumi Vasıf Bey, "Dünyada hiçbir kanun, bilhassa hürriyet-i fikriye ve hürriyet-i vicdaniyi müdafaa eden Türkiye Cumhuriyeti kanunları Lütfi Fikri Bey'in dimağına nüfuz ederek onun efkarını takip ve tecrim etmez. Fakat bu fikir ve kanaatler herhangi bir suretle, herhangi bir vasıta ile kavlen olsun, tahriren veya fiilen olsun ızhar ve neşir edilirse kanunun memnuniyetine muhalif bir hareket irtikap edilmiş olur" demiştir. Çulcu, age., II, s. 197.
} 
Reis- Biz sizi aynı zamanda manevi muhakeme karşısında bulunduruyoruz?

Lütfi Fikri- Hazırım efendim”.

Mahkeme Başkanı, Lütfi Fikri’nin İkinci Meşrutiyet dönemi muhalefetini sorguladıktan sonra sıra 1923 yılındaki muhalefetine gelmiştir. Burada Lütfi Fikri, evinde yapılan aramalarda bulunan hatıratındaki bazı ifadeleri üzerinden sorgulanmıștır. Mahkeme Başkanı Lütfi Fikri’ye hatıra defterine 14 Mart 1923 tarihinde yazdığı "Meşrutiyet Furkası namıyla tamim ettiğim bir firka-i siyasiye için bir program ve nizamname-i dâhili müsveddesi yaptım. Ankara'da İkinci Gruba gönderdim. ${ }^{39}$ Sulhtan sonra projeye germi verilecek" ifadesini hatılattıktan sonra bu ifadesini izah etmesini ve İkinci Gruba ne gönderdiğini anlatmasını istemiştir.

Bunun üzerine Lütfi Fikri, bir firka programı ve nizamname müsveddesi gönderdiğini söylemiştir. Başkan, kime gönderdiğini sorunca da 'Zan ederim Selahattin Bey'e $e^{40}$ (Köseoğlu), bendeniz kendisini tanımazdım. Bir mektup yazmıştı. Bendeniz de cevap olarak yazdığım bir mektup da öyle bir şey göndermiştim” demiştir.

Mahkeme Başkanı programın neyi amaç edindiğini sorunca Lütfi Fikri Bey, meşrutiyet firkası olduğunu söylemiştir: "Evrakım arasında da vardır. Meşrutiyet fırkası idi. Bir şey istirham ederim. Malum-1 devletinizdir ki Hıyanet-i Vataniye Kanunu'nun son almış olduğu tefsire nazaran şekl-i idare hakkında bir şey yapmak cürüm olduğu gibi bu babda mütalaada cürümdür. ${ }^{41} \mathrm{Bu}$ babdaki maruzatımı mahkeme-i celilenize ancak itaat için yapıyorum. Bu suretle mahkeme-i celileniz mütalaamı dinlemek suretiyle bir lütuf buyurmuş olur".

Daha sonra yargılama şöyle devam etmiştir:

"Reşit Galip Bey- Onlar nazariyattır.

Reis- Bütün milletin vekâletini haiz olan büyük millet meclisinin kudret-i kazaiyesini haizdir. Biz memleket nokta-i nazarından muhakeme yapıyoruz.

Kılıç Ali Bey- Nazariyatı bırakınız da cevap veriniz.

Lütfi Fikri- Nazariyat değil efendim. Mahkeme-i celileniz emrediyor, ben de söylüyorum.

Reis- Peşin söyledim. Müsterih olunuz. Hak ve hakikat ve memleketin istikbal ve selameti nokta-i nazarından vaziyetinizi tespit edeceğiz.

\footnotetext{
39 ilk Mecliste, 10 Mayıs 1921 tarihinde Mustafa Kemal Paşa tarafından kurulan Anadolu ve Rumeli Müdafaa-i Hukuk Grubu (ARMHG) I. Grup olarak adlandırılmıştır. IIlk TBMM'deki 437 mebusun 202'si I. Grubun üyesidir. Temmuz 1922'de I. Grubun karşısında II. Müdafaa-i Hukuk Grubu yani II. Grup kurulmuştur. Hüseyin Avni Bey tarafından kurulan bu grup 63 mebustan oluşmuştur. II. Grup hakkında geniş bilgi için bkz. Ahmet Demirel, Birinci Mecliste Muhalefet, ìstanbul 2007. ${ }^{40}$ Mersin Mebusu Selahattin (Köseoğlu) Bey II. Grubun yedi kurucusundan biridir. Demirel, age., s. 380.

${ }^{41} 1923$ seçimleri öncesi 15 Nisan 1923 tarihli Meclis oturumunda 334 ve 335 numaralı kanunlarla seçimlerin ve rejimin güvenliği için Hıyanet-i Vataniye Kanunu'nda değişiklik yapılmıştır. Yapılan bu değişiklikle saltanatın kaldırılmasına dair 1 Kasım 1922 tarihli kanun aleyhinde sözlü, yazılı ve fiili eylemler vatan hainliği olarak kabul edilmiştir. Değişikliğe en büyük tepkiyi Lütfi Fikri Bey vermiştir. Lütfi Fikri Bey, Tevhid-i Efkâr'daki makalesinde, "Böyle bir kanun ancak ihtilal devreleri ve onların da en vahim-i vihad bir şekil ve suret aldığı zamanlar için kabil-i tasavvurdur" diyerek değişiklik önerisini şiddetle eleştirmiştir. Tekin Demiraslan, "1923 Milletvekili Seçimleri ve Basın", Ahi Evran Üniversitesi Sosyal Bilimler Enstitüsü, Yayımlanmamış Yüksek Lisans Tezi, Kırşehir 2013, s. 80-81.
} 
Lütfi Fikri- Maneviyatımı tespit etmiş olacaksınız. Arz ettim. Bunlar dimağındaki fikirlerdir, ilk defa emr-i devletleriyle meydana çıkıyor.

Reis- Millete göstermek istiyoruz.

Lütfi Fikri- Her halde cürüm telakki buyurmayacağınızı ümit ediyorum.

Müdde-i Umumi- Lütfi Fikri Bey bu mesele üzerinde çok 1srar ediyor. Heyet-i celileri de kendisine lazım gelen tebligatı yapmıştır. Fikir ve niyet ve ruhta istenilen amal ancak teşebbüs sahasına girdiği zaman cürüm olur. Okunan şey gazetelerde neşredilmiş olsa dahi 1923 tarihini muhtevi bulunması hasebiyle mürur-1 zamanda aff-1 umumi kanunu ilan edilmiştir. ${ }^{42} \mathrm{Bu}$ cihetten müsterih olsun. Yalnız kendisini tarikat-i fesadiye meselesinden dolayı takip ediyoruz. Tarikat-1 fesadiyenin takip ettiği yol cumhuriyet aleyhindedir. Binaenaleyh kendisinin Tarikat-1 Salahiye ile alakadar olduğu maznunlardan birçok eşhasın ifadeleri ve evrakta mevcut başka vesaik ve delalil ile zan edilmektedir. Yalnız heyet-i celileri Lütfi Fikri Bey'in cumhuriyet aleyhtarı olduğunu millete göstermek için bunları okuyor. Tarihi 1923 değil 1910 bile olsa veyahut yeni tespit edilmiş bile olsa herhalde efkâr-1 umumiyeye arz edilmesi elzemdir. Çünkü cürmü yalnız afaki olarak değil Lütfi Fikri Bey’in şahsiyeti itibariyle mütalaa etmek lazımdır. Lütfi Fikri Bey’in ne düşündüğünü heyet-i celileniz öğrenmeye mecburdur. Bunun neşredilmesi herhalde lazımdır.

Maznun- Müdde-i umumi beyefendinin beyanat-1 alileri beni temin etti’.

Bu konuşmalardan sonra Lütfi Fikri'nin 1923 yılına ait günlüğü okunmuştur. Lütfi Fikri 13 Mart 1923 tarihli günlüğünde Ocak ve Şubat aylarında defterine bir şey yazamadığını, zira bu aylarda bir firka-1 siyasiye programı ve nizamname müsveddesi hazırladığını ${ }^{43}$, hatta bu programı "teati-i efkâra" vesile olması için Meclisteki İkinci Gruba gönderdiğini yazmış ve şöyle devam etmiştir: "Esasen bu grup da bana büyük bir sempati gösteriyor. Böylece biz tedricen ağır ağır birleşmiş olacağız. Fakat niçin ve ne maksatla? Bu her iki tarafin ve memleketin menfaati için vazıh ve sarih olarak tespit olunmalıdır. Hâlbuki maatteessüf hal-i harbin temadisi bu vuzuh ve sarahatin bir an evvel husulüne mani oluyor. Her şey gibi o da "inşallah harpten sonra!" formülüyle mütemadiyen teehhüre uğruyor.

Afak-1 siyasiye-i memleket çok muzlim ve bulutlu! .. Eğer bu Meclis kararı üzerine İngiltere taallül göstermezse artık bu sefer sulh-1 harici olur ümidindeyim. Ben bu babda oldu olalım İngiltere için tereddüt ve endişedeyim. Onun sulhu samimiyetle istediğine hâlâ kani olamadım. O daima işlerin teehhüründen kendisi için fayda beklemiştir. Kaldı ki bizim dört beş aylık vakayi-i dâhiliyemiz ona bu babda bir kat daha ümit ve cesaret verecek mahiyettedir. Memleket artık maatteessüf artık müttehit değildir. Hani o zafere kadar gelen devre! O vakit Ali Kemal ve nihayet yüzü geçemeyecek bir hizb-i kalil müstesna olmak üzere bütün millet Kuva-yı Milliye ile beraberdi.

\footnotetext{
42 TBMM tarihindeki ilk genel af yasası 7 Ocak 1922 tarihinde çıkarılmış ve bu tarihte toplam dört maddeden oluşan yasa ile cezalarının üçte ikisini tamamlayan mahkûmların kalan cezaları affedilmiştir. Cumhuriyet'in kuruluşundan kısa süre bir sonra 26 Aralık 1923 tarihinde ikinci genel af yasası çıkarılmıştır. Bu düzenlemeyle, 29 Ekim 1923'e kadar işlenmiş suçlara verilen cezaların yarısı affa tabi tutulmuştur. http://www.hurriyet.com.tr/gundem/turkiye-tarihinde-af-yasalari74638

${ }^{43}$ Bu fırka program taslağı Lütfi Fikri’nin ilk hazırladığı program değildir. Lütfi Fikri 1912 yılında İttihat ve Terakki ile Hürriyet ve İtilaf'tan ayrı olarak Müceddidin adında bir fırka kurmak istemiş ve gazetesinde bir program yayınlamıştır. Ancak Bab-ı Ali Baskını olunca bu teşebbüsü akim kalmıştır. Bu fırka girişimi için bkz. Ahmet Ali Gazel "Il. Meşrutiyet Döneminde Projede Kalmış Bir Fırka Teşebbüsü: Müceddidin Fırkası," Tarih ve Toplum, 36/211, Temmuz 2001, 46-49.
} 
Hâlbuki bu Teşkilat-1 Esasiye meselesinden sonra memleket azim bir tefrika içindedir. İngiltere elbette bunu görüyor ve ondan lazım gelen istihraç ve istintacı yapıyordur!..

Mustafa Kemal Paşa ve arkadaşları için ne dahi (?) illusion! Misak-1 Milli'de muvaffak olan azimleri mutlaka Teşkilat-1 Esasiye hususunda da maksada ermek için kâfi imiş! "Azim” yalnız kâfi gelemez. Zaferi yalnız azim hazırlamamıştır. Muhitin yardım edemediği hususatta yalnız "azim" akim kalmaya mahkûmdur.

Zaten daha şimdiden müstakbel, görmeye alışmış gözler için az çok belirir olmaya başladı. Mustafa Kemal Paşa'nın balonu hilafet ve saltanat hakkındaki 2 Teşrin-i sani tarihli karardan sonra delindi. O vakitten beri sukut ediyor. Bunların yalnız biri yirmi Mustafa Kemal Paşa aşındırmaya kâfidir!... Bu münasebetle hatırıma geldi: Bizim bu şimdiki devremizin tarihte en ziyade benzetilebileceği devrelerden biri olan İngiltere devre-i inkılabiyesinde Cromwell hiç böyle hareket etmedi. Onun kendisine mahsus bir fikir ve kanaati yoktu. O herkesi memnun ve bütün mesuliyetleri Meclise tahmil etmek istiyordu. Pusu kurmuş firsat bekliyordu.

Hâlbuki Mustafa Kemal Paşa bunun büsbütün aksini yapıyor. Şahıs itibariyle bu iyi bir not olabilir. Fakat o nispette de muvaffakiyetsizlik artar!..

Paşa'nın İttihat ve Terakki ile anlaşıp anlaşamaması meselesi hâlâ bir sarahat ve vuzuh iktisap edemedi. İttihatçılar pek sulb adamlardır. İcabında her şekle girebilirler. Binaenaleyh bugün Paşa İttihatçılarla birleşirse akıbet bir Mahmut Şevket Paşa olmaya mahkûmdur. Zamanı geldi mi İttihatçlar onu bir encombrement ${ }^{44}$ addederek istiskal edip bir tarafa atarlar yahut bir kurşun ile ecarter ederler!".

Lütfi Fikri Bey günlüğ̈̈nde, aynı kanaati bir önceki gün İzmir İktisat Kongresi’nde bulunmuş ve oradan yeni dönmüş bir kişide de gördüğünü ve bu kişinin kendine aynen şunları söylediğini yazmıştır: 'İzmir'de Mustafa Kemal Paşa'ya anlattım ve hele Kâzım Karabekir Paşa'ya pek sarih olarak söyledim. İttihatçılar akıbet Mustafa Kemal Paşa'yı Nâzım Paşa mevkiine getirecekler ve bir kurşunla işin içinden çıkacaklar. Doktor Nâzım ve birçok mühim İttihatçılar el-yevm İzmir'dedir. Ve esasen muntazam olan teşkilatlarına bir kat daha kuvvet veriyorlar". İttihatçılarla birleşip birleşmemek meselesi benim için de varittir. Bakılır ise mademki ben malum olan ilk risale ile Teşkilat-1 Esasiye'ye karşı pek sarih bir vaziyet almış oldum. Artık Mustafa Kemal Paşa ve taraftaranı ile bir uçurum açılmış demektir. O halde gerek Ankara'nın iki numaralı grubu ve gerek İttihat ve Terakki'nin bakıyetüssüyufu benim en tabi müttefiklerim demektir. Kaldı ki bu kadar tırpan yemiş en büyük rüesasını kaybetmiş olan İttihat ve Terakki'nin bundan sonra saha-i faaliyette birinci rol oynayabilmesi müşahadat-1 tarihiyeye nazaran müstahildir. Zannolunur ki o daha ziyade ikinci derecede bir rol oynamaya mahkûm, bir second brillant kalmaya mahkûmdur. Eğer şu muhakemat ve tahminat doğru ise onlar ile ne için tevhid-i mesai edemeyim? Doğrusu bu mühim ve nazik bir meseledir".

Lütfi Fikri Bey, 14 Mart 1923 tarihli günlüğünde de aynı konuya değinmeye devam etmiştir. Meşrutiyet Fırkası adıyla bir program ve dâhili nizamname müsveddesi hazırladığını, Ankara'da İkinci Gruba gönderdiğini ve barıştan sonra projeye hız verileceğini yazmıştır. Lütfi Fikri, programına önemi ikinci üçüncü dereceden konuları almadığını, durumun nezaketine binaen de açıktan açığa hükümdarlık taraftarı olmadıklarını belirttiğini, ancak bu kısa programdan maksadın tamamen tezahür ettiğini ifade etmiştir. Daha sonra şöyle devam etmiştir: "Yeni meselelerin

${ }^{44}$ tıkanıklık 
programa ithalini firka kongrelerine bırakıyorum. Nizamname-i dâhilîde ise eskiden yaptığımız gibi firkayı memleketin bir nüfus idaresi haline getirmek istemedim. Tecrübelere nazaran yalnız merkez-i umumi ve şubeler teşkilatı yapmak ve onları İngiltere'de olduğu gibi propaganda merkezleri halinde bulundurmak ve fakat firkaya efrad yazıp kart verme gibi usullere rağbet etmemek bana daha pratik göründü. Ben bu firkayı mutlaka inkişaf ettirmeliyim. İkinci Grupla olursa daha iyi olur. Yok, onlar tereddüt gösterirler ise merkezi İstanbul'da olmak üzere ahvalin en münasip ve en müsait tecellisinde ben bunu kendim yapmalıyım. Çünkü hükümet akıbet bir firkanın eline gidecektir ve gitmelidir. Memleket hâlâ bir devre-i ihtilaliye yaşıyor. Bir memleketin mesut olmasi kat'iyen ihtilalciler eliyle olamaz. Bu emr-i hayr mutlaka onlardan sonra olacaktır. $\mathrm{Bu}$ Mustafa Kemal Paşa taraftaranı -ki pek mahduttur- İttihatçılar ile akıbet birbirleriyle bıçak bıçağa gelecekler ve birbirlerini tahrip eyleyecekler. Şimdiden makul bir firkanın esasatını kuracak olur isem tedricen o büyük ve kök atar ve ihtilalciler birbirini yedikten sonra o firka bihakkın mevki-i iktidara gelir ve muhakkak memlekete büyük hizmet ifa eder." 45

Günlüğü okunduktan sonra Lütfi Fikri, içinde bulunduğu haleti ruhiyeyi şöyle izah etmiş̧tir: "Bendenizin vaziyetim yerinde rahat otururken bir rüzgârla çatıların uçup gitmesi ve kendisinin ortada kalması halini hatırlatıyor. Hiçbir gün hatır ve hayale gelmezdi ki samimi yazılarımla bu vaziyet karşısında kalayım. Yine samimiyetle ifade ediyorum ki pek nahoş şeyler var. Fakat memleketime hıyanet etmiş değilim. Hüsn-i adalet ve insafınıza müracaat ediyorum".

Bunun üzerine Mahkeme Başkanı, "Böyle bir zihniyet samimiyetle kabil-i telif midir, siz söyleyiniz?" diye sormuştur. Lütfi Fikri de "Neşretmiş miyim?" diye mukabelede bulunmuştur. Daha sonra Başkan, "Edeceksin. Yani Vahdettin'i getireceksin?" diye devam edince Lütfi Fikri şöyle cevap vermiştir:

"Estağfurullah Meşrutiyet Fırkasını getireceğim. Bunu cumhuriyetin bahşettiğine kanaat ettiğim hürriyet-i içtihada binaen arz ediyorum. Olabilir ki fazla safvet göstermişim. Malum-1 aliniz Fransa'da cumhuriyet olmasına rağmen resmen kral taraftarı firkalar var. Sırf meşruiyet silahlarıyla mücadele edecek firkalara cumhuriyet-i idare müsaade etmiştir diye yapmışım. Bu da benim cumhuriyet-i idareye karş1 emniyet ve merbutiyetimi gösterir. Fakat cumhuriyet-i idare sonradan ahval-i fevkalade dolasıyla şiddetli hareket etmek mecburiyetinde kalmıştır. Bendeniz de o suretle İstanbul İstiklal Mahkemesi'ne gitmişim ve orada mahkûm olmuşum. Fakat ondan sonra Büyük Millet Meclisi'nin affina mazhar olmuş ve intibah hâsıl etmişimdir. Müttefikan Büyük Millet Meclisi bendenizi affetmişti... Ondan sonra anladım ki su-i niyetten ari gördüğümüz için seni affediyoruz. İçtihadından dolayı böyle uzun müddet hapis tutmuyoruz, çıkarıyoruz. Fakat artık böyle şeylerle meşgul olma sus, denilmiştir. Ben bunu böyle telakki ettim ve bana artık namuskârane susmak düşer dedim ve ondan sonra kat'iyen siyasetle iştigal etmedim bir satır yazı yazmadım".

$\mathrm{Bu}$ sözlerinden sonra Başkan, "Şimdi nasılsınız, kanaatleriniz tebdil etti mi?" diye sormuş ve yargılama şöyle devam etmiştir:

"Lütfi Fikri- Efendim cumhuriyet-i idareyi ele alalım. Cumhuriyet-i idare bir tarz-1 idaredir. Mutlak olarak cumhuriyet-i idare iyidir veya fenadır denilemez. Zamana göre beşeriyetin bir eseri tekemmül olarak vücuda getirdiği bir şekli-i idaredir. Hakikat budur. Eski risalelerimde de bundan

${ }^{45}$ Günlüğündeki görüşlerinden dolayı gazetelerde Lütfi Fikri hakkında oldukça olumsuz yorumlar yapılmıştır. Bkz. "Lütfi Fikri Bey Nasıl Bir Adamdı?", Cumhuriyet, 27 Temmuz 1341, s. 1. 
uzun uzadıya bahsetmiştim. Cumhuriyet-i idarede reis-i cumhurun müntehib olacağına sülale takip etmesini kabul eden hükümetler vardır. Ezcümle Belçika, İngiltere tamamen buna bir misaldir. Orada da hâkimiyet-i milliye tamamen inkişaf etmiştir. Reis-i devlet müntehib olacağına diğer şekilde olsun her devletin kendine mahsus ananâtı vardır. Onun hiçbir tesiri olamaz. Bendeniz meşrutiyet taraftarı olarak telakki olunuyorum. Fakat emin olunuz ki bendenizin meşrutiyet taraftarlığım bir seccadeci başının meşrutiyetiyle bir değildir.

Reis- Bir milletin şerifleri, seyitleri, padişahları, halifeleri millete hizmet edenlerdir (Seyyid-ülkavmi hadim). Memleket bir Mondros Mütarekesi'yle inhilal derecesine gelmiş, her taraf işgal edilmiş millet gözyaşı döküyor elinden top, tüfek alınmış kan ağlıyorken başta mütefessih bir hanedan oturacak, padişah, halife olacak. Beyefendi, millet isbat-1 rüşt etmiştir. Millet kanıyla hâkimiyetini almıştır. Artık kimseye veremez! Binaenaleyh siz bundan ne hakla bahsediyorsunuz?

Lütfi Fikri- Bendeniz de onu arz edecektim. Müsaade buyrulsa idi itiraz-1 devletlerine meydan kalmazdı. Bendeniz böyle şeyler vardır demek istiyorum. Biz ilim intisabı iddiasındayız. Malum-1 devletleri ilim intisabında olanlar inkılabcı olamıyorlar. Tedrici tekâmül taraftarıdırlar. Ürküyoruz korkuyoruz. En fena bir şeyi tebdilde tereddüt ediyoruz ve kuşkulanıyoruz. Halet-i ruhiyemiz böyle, meşrutiyet demekle hükümdarlığı göklere çıkardığımızdan değil, vücudunu kaldırmaktan korktuğumuzdandır. ${ }^{46}$

Reis- Öyle değil, mugalata yapıyorsunuz. Bütün fikirlerinizi defterinizde tespit etmişsiniz. İstinat ettiğiniz esbab-1 mucibe İttihat ve Terakki'nin bakiyyetü's-suyûfu şu olacak, İkinci Grup şu olacak bu olacak meydan bana kalacak. İşte istinat ettiğin esbab-1 mucibe budur. İşte defterin önümüzde, sözlerin mugalatadır. Elan efkâr-1 umumiyeye karşı mugalata yapmak istiyorsun. Bütün hayatınızda böyle yapmışsınızdır.

Lütfi Fikri- Müsaade buyurunuz 324 (1908) senesinden bu güne kadar dünya nazır oldu. Ben istese idim.

Reis- Buna dair hususi fikirlerin vardır. Ve kardeşinin de fikirleri vardır. Müdavele-i efkâr etmiş ve tamamen tespit etmişsiniz?

Lütfi Fikri- Belki yapılmıştır.

Reis- Evet istinat ettiğin nokta ne hukuk-1 esasiye ne teşkilat-1 esasiyedir. İstinat ettiğin nokta en çürük ve nazariyeniz memleketin felaketini davet edecek bir nazariyelerdir.

Lütfi Fikri- Efendim bendeniz şahsi olarak bir mevki yapmak isteseydim zaferden sonra herkesin dediği gibi tamamen ağaçların meyve vermeye başladığı zamanlarda kendimi tarik-i muhalefete atar $\mathrm{m}$ idim.

Reis- O bir ruhtur, bir zihniyettir".

\footnotetext{
${ }^{46}$ Cumhuriyet’te İzzet Ulvi, Lütfi Fikri'nin “Biz ilim intisabı iddiasındayız. Malum-ı devletleri ilim intisabında olanlar inkılapçı olamıyorlar. Tedrici tekâmül taraftarıdırlar" sözlerine tepki göstermiştir: "Lütfi Fikri... Söz söylemek, izah etmek bile zaittir. Şimdiye kadar memlekette Lütfi Fikri hep menfi çalışmış, zehrini sönmez ihtirasını bir türlü teskin edememiş, fikirsizliklerini bir türlü anlayamamış bir haindir. "Fikir de mi tekâmülcü olurmuş. Birden inkılabı anlayamamış, saltanat ilga edilirse karışıklıklar hâsıl olacak sanmış imiş". İstikbali göremeyen, vücut bulan inkılabı anlayamayan bir birinin ilimden bahsetmesi garip olmaz mı? Hayır, maksadı her ne şekilde olursa olsun ihtirasını tatmin etmektir....", İzzet Ulvi, "Mesul Kim", Cumhuriyet, 456, 16 Ağustos 1925, s. 2.
} 
Daha sonra Müdde-i Umumi Reşit Galip Bey araya girerek "Evvelen Anadolu ile anlaşmak için Anadolu taraftarlığının mahiyeti ve har bir surette neşriyatta bulunmaktaki kanaat ve maksatları tavzih edilsin. Ben bütün neşriyatında Anadolu taraftarlığı ve Anadolu'daki hareket-i milliyenin müdafaası cihetini görmedim. Fakat padişahlık müdafaasını gördüm. Orada diyorsunuz ki padişahım kendini sıkı tut, Anadolu kuvvetleniyor padişahlığı hilafeti muhafaza etmek istersek Anadolu'daki ussatla anlaşmak lazımdır. Böyle diyorsunuz. Gerek padişaha verdiğiniz hususi arizalarda gerek matbuata verdiğiniz makalat içinde benim anladığım budur" dedikten sonra "Binaenaleyh bu nokta iyice tespit edildikçe ben en hararetli Kuva-yı Milliye taraftardarlarındanım demenize razı değilim" diye devam etmiştir.

Lütfi Fikri’nin buna cevabı şöyle olmuştur: “Anadolu ile temasımız gayet mahdut olduğu için burada hükümran olan halet-i ruhiyeye vakıf değilim. Zaferden sonra hâkimiyet-i milliye esasına müstenit cumhuriyet-i idare tesis ediyor. Bir her ne şekilde olursa olsun hanedan için hiç bir mesele yoktu. Ben bütün ruhumu açarak samimi olarak söylüyorum. Hanedanın ihracını istemiyordum. Bilhassa o zaman içinde Vahdettin tard edilmeli diyordum, oldu. Ondan sonra bir gün Vahdettin gelsin diye hatır ve hayale getirmedim. Fakat Vahdettin'den sonra da padişahlık kalksın diye de hatırıma getirmemiştim. Nasıl ki Fransa'da ilk defa meşrutiyette hanedanı kaldırmadılar, hanedanı daima bir tarafa birakarak millet inkılabını yapıyordu. Demek oluyor ki bu bize mahsus bir haldir. Ben hanedana ilişilmez zan ediyordum. Neşriyatımda buyurdukları tarzda bir şey varsa onları Anadolu'ya meylettirmeye matuftur. Padişahım kendini kurtar Anadolu'yu ez tarzında bir şey aklıma gelmezdi ve gelemezdi. İlk defa Refet Paşa'nın İstanbul'a vürudunda bazı noktalarıyla bu mesele tecelli etmeye başladı. Binaenaleyh bendeniz sırf saltanatı ve hilafeti muhafaza etmek kaydıyla Kuva-yı Milliyeyi müdafaa ettiğimi zan etmiyorum ve böyle tefsire uğrayacağından ümitvar değildim. Bu şekilde tefsire uğradığından dolayı çok müteessirim. Hatta bu makalelerden bir tanesini İstanbul İstiklal Mahkemesi'nde okumuşumdur. Evrakım yanımda olsa idi zat-1 devletlerine de arz ederdim. Makalemde Ali Kemal'e, bize sükûnet tavsiye ediyorsun. Selhhaneye giderken kurtulmuş hayvanlar vardır. Biz o kadar da mı olmayalım. Bizi kaderimizle yalnız bırakınız, belki kendimizi kurtarırız diyordum. Şimdi padişahlığı müdafaa ettiğimi söylemekliğiniz doğrusu pek gücüme gitti.

Lütfi Fikri'nin bu cevabı sonrası yargılama şöyle devam etmiştir:

"Reşit Galip Bey- Bütün neşriyatınızdan ve bütün makalatınızdan anlaşılan nokta şudur ki: Anadolu'da çalışan insanların istihdaf ettikleri selamet-i milliye ve istikbal-i vatan gayeleri ikinci kademede kalsın, hanedan kendisini kurtarmak için nasıl Fransızlarla İngilizlerle anlaşmış ise Anadolu'dakiler de anlaşsın ve bu anlaşma üzerine padişahlık kurtulsun. Şurada padişaha suret-i hususiyede yazılmış veyahut neşredilmiş bir mektubunuz var. Vahdettin'in atebe-i felek mertebesine hitap ediyorsun ${ }^{47}$, Anadolu mücahitlerinden bahsederken tamamen ussat ve bağiler tabirlerini istimal ediyorsunuz?

\footnotetext{
47 Lütfi Fikri Cenevre'de iken, yeni padişah olan Sultan Vahdeddin'e 23 Ağustos 1918 tarihinde ilginç bir mektup yazmıştır. Lütfi Fikri bu mektubunda, Sultan Vahdettin'i meşrutiyetin “ilk hakiki padişahı” olarak nitelendirdikten sonra yıllarca mücadele ettiği ittihatçıların köklü bir yapıya sahip olduklarını, dolayısıyla dışlanmalarının memleket için hayırlı olmayacağı üzerinde durmuştur. Lütfi Simâvî, Son Osmanlı Sarayında Gördüklerim, İstanbul 2004, 278-283. Lütfi Simavi Bey, Lütfi Fikri'nin bu mektubunu şöyle yorumlar: "Lütfi Bey'in kişisel ihtiraslarından uzak görünen bu tasarısı, dilinin ılımlılığı, fikirleri ve düşünceleri ile bir vatanseverlik belgesi niteliği taşıyordu. Bu nedenle kendisini kalpten tebrik ettim", Lütfi Simavi, age., s. 283.
} 
Lütfi Fikri- Efendim o zaman başka türlü yazılabilir mi idi?

Kılıç Ali Bey- Yazmaya mecbur mu idin?

Lütfi Fikri- Fakat orada diyorum ki bunlar sizin evlatlarınızdır, siz bunlarsız bir şey yapamazsinız. Bu memlekette onlarsız bir şey yapmak felakettir.

Reşit Galip Bey- Sizi bu şekilde yazmaya sevk eden nokta hanedandır. Hanedan için endişe his ediyorsunuz ve o endişeyi kendisine telkin etmek istiyorsunuz?

Lütfi Fikri- Öyle mi, yoksa hanedanı itaate sevk etmekle memleketin matlup olan vahdet ve selametini daha kolay temin etmek endişesi midir?

Reşit Galip Bey- Yazınızdan bunu anlayabilmek için ayrıca izahat-1 alilerini dinlemek lazım geliyor.

Lütfi Fikri- Efendim demin de arz ettim. Benim bu makalemden bazıları o zaman Anadolu Ajansi tarafindan Anadolu'da tamim olundu.

Reşit Galip Bey- Sonra dediniz ki: İlim ile mütevaggıl olmak itibariyle inkılap şeklinden ziyade tekâmül şeklini benimseriz ve o yol üzerinde yürümek isteriz. Şimdi şu hatırada mevzu-1 bahs edilen İttihatçılarla Mustafa Kemal Paşa taraftarlarının bıçak bıçağa gelerek birbirlerini tahrip etmeleri ve ondan sonra sizin teşkil edeceğiniz firkaya meydanın boş kalması tasavvuru da kanun1 tekâmül ilmi iktizasından mıdır?

Lütfi Fikri- Efendim inkılap tarihini yazan, herhangi bir ihtilal tarihini yazan hukukşinasın eserlerini tetkik ederseniz bu fikirleri görürsünüz: "İhtilal çocuklarını yer" derler. Bendenizin oraya yazdığım ihtilal hakkında takarrür etmiş hakayık-1 ilmiye ve içtimaiyedir diyemem. Acaba mütalaatım doğru çıkıyor mu, çıkmıyor mu diye kendimi bir yoklamaktan ibarettir.

Reşit Galip Bey- Beyefendi işin içine şahsi tasavvurlarınız doğrudan doğruya şahsınız mevzu-1 bahs olduğu için şu mütalaat-1 ilmiye temenni mahiyetini alıyor. Bunlar birbirilerini yesinler, öldürsünler ortada leşleri kalsın ben de o leşlerin üzerine çıkayım diyorsunuz.

Lütfi Fikri- Estağfurullah efendim.

Reis- Öyle ya meydan size kalacak. O onu vuracak öbürü diğerini vuracak meydan size kalacak. Teşkil edeceğiniz fırka faaliyete geçecek. Yazdıklarınız aynen şunlardır: "Akıbet birbirleriyle bıçak bıçağa gelecekler, birbirlerini tahrip edecekler. Şimdiden yeni firkanın tohumunu atacak olursam tedricen büyür, kök atar ve ihtilalciler birbirini yedikten sonra o firka mevki-i iktidara çıkar" diyorsunuz.

Lütfi Fikri- Rica ederim efendim bir recül-i siyasi bir firka yaptığı vakit rüzgara pamuk ekmek kabilinden bir şey yapar mı. Zamanı görür, kendisinde haklı veya haksız bir kanaat hâsıl olur. Herhangi bir adam firka yapar da onun hiç olduğunu kabul eder mi. ${ }^{48}$

Reis- Fırka vatan içindir, gayesi vatanın alâsıdır. Böyle bir takım ihtilallerin neticesine istinat ettirilecek ve memleketin dâhili ve harici vaziyeti nazar-1 dikkate alınmayacak, ondan sonra birbirimizi yiyeceğiz, sen de firka teşkil edeceksin. Senin bu tasavvurun vücuda gelirse vatan ne olur ve harici düşmanların istediği de sizin istediklerinizden başka bir şey midir?

48 "Lütfi Fikri Bey'in Mahkemesi”, Hâkimiyet-i Milliye, 1486, 29 Temmuz 1341, s. 1-2. 
Lütfi Fikri- Efendim başka türlü ne yapabilirdim. Müessir rol oynayamam. Mütalaatımı kimseye arz edemem. Zafere kadar az çok min gayr-i haddin çalıştım. Onları hulus-1 niyetle yazdım. Vatanperverlikle yazdım. Fakat beyefendi ondan bazı kuyud-1 ihtirazi dermeyan ediyorlar. İçtihatlarıdır. Zaferden sonra ahval büsbütün başka türlü tecelli etti. O tecelli eden ahvalde bendenizin bir rolüm yok. Bir mebus değilim ki fikrimi söyleyeyim. Bana susmak kaldı. Zan ederim ki her okumuş adamın böyle bir hatıratı vardır. Hatırat demek şahsın dimağıdır. Bir insan müteessir zamanı olur, kötü düşünür. Bazı zaman olur münşerih olur, iyi düşünür. Hiçbir gün hatır ve hayale gelmemiş ki bu hatıram mahkeme-i alilerine gelecek ve burada bunun hakkında izahat vereceğim.

Reşit Galip Bey- Şunu söylemek lazımdır ki bu kadar meşum düşünenler, kaydedenler pek nadirdir.

Reis- Düşünceleriniz pek meşumanedir. Düşünceleriniz memleketin felaketini davet edecek düşüncelerdir.

Lütfi Fikri- O sirada birisi bendenize gelip de aman şu felaketin önüne gitmeyelim demiş de, hayır ben öyle istemiyorum evvela bunlar birbirlerini kırsınlar falan demiş miyim. İşte beyefendi o zaman vicdansız olmaklığım lazım gelir”.

Daha sonra Mahkeme Başkanı, Müdde-i Umumi Reşit Galip Bey'in soruları olacağını belirttikten sonra Lütfi Fikri'nin bunlara cevap vermesini istemiş ve yargılama şöyle devam etmiştir:

"Reşit Galip Bey- "Bir program ve nizamname yaptım ve İkinci Grup aza-yı müteneffizesine gönderdim" diyorsunuz. Bu İkinci Grup azayı müteneffizesi diye telakki ettiğiniz zevat kimlerdir?

Lütfi Fikri- Demin arz ettim efendim, Selahattin Bey.

Reşit Galip Bey- Fakat bu "azayı müteneffizesine” kelimesinde bir cem manası var.

Lütfi Fikri- $\mathrm{O}$ sırada ismi geçen zevat.

Kılıç Ali Bey- Kimlerdir bir de sizin ağzınızdan işitelim

Lütfi Fikri- Hatırıma Selahattin Bey geliyor.

Reşit Galip Bey- İkinci Grup denildiğine göre o vakit Birinci Grup da vardı. Mütalaanız neden dolayı İkinci Grup aza-yı müteneffizesine gönderilmiştir de Birinci Grup aza-yı müteneffizesine gönderilmemiştir. Mademki siz İstanbul'da bi-taraf olarak memleket için bazı şeyler düşünüyorsunuz.

Lütfi Fikri- İhtimal ki İkinci Grubu meşrutiyete daha müsait görmüşüm de onlara yazmışımdır.

Reis- Memleketin en mühim aksamını düşman işgal etmiş muharebe devam ediyor. Bütün millet silahaltında aç, açık, sefil bir taraftan kağnılarla cephane taşıyor, o da bulunmazsa arkasında taşıyor. Düşmanın, henüz memleket dâhilinde bulunduğu bir sırada İkinci Grubu o suretle bir vaziyet almış mevkiinde görüyorsunuz ve onları daha ziyade teşvik ediyorsunuz.

Lütfi Fikri- Hayır efendim bunlar istihbarat kabilindedir, bunu gönderdim ise de sulhun tesisinden sonra tatbik edilmesi lazım olduğunu da yazdım.

Reşit Galip Bey- "İkinci Grupla böylece tedricen ağır ağır birleşmiş olacağız. Fakat niçin ne maksatla?" diye bir sual soruyorsunuz. 
Lütfi Fikri- Demek daha mühim imiş efendim.

Reşit Galip Bey- Böyle niçin ne maksatla birleşilmiş olduğunu bilmemek bilhassa sizin gibi siyasette, politikada üstat geçinen zevat için layık mıdır?

Lütfi Fikri- Efendim arz ediyorum. Yalnız bendeniz cumhuriyet-i idarede böyle şekl-i idarenin harici bir firka, meşrutiyet firkası yapılabilir kanaatinde idim. Fakat bunun imkânı olmadığı Hıyanet-i Vataniye Kanunu'nda takarrür ettiği vakit hepsini bıraktım. Bu yazıları Fransa'da olduğu gibi cumhuriyet-i idare dâhilinde meşrutiyet fırkasının tesis edebilmesi ihtimali üzerine yazmışımdır.

Reşit Galip Bey- Siz daha meşrutiyet hakkındaki efkâr ve mütalaanızı neşretmeden evvel defterinizdeki hatıratınıza nazaran bu grup size bir sempati göstermiştir.

Lütfi Fikri- Bendenizin ilk risalem ${ }^{49}$ daha evvel çıkmıştır. Bu ondan sonradır.

Reşit Galip Bey- O risaleden sonra mı aranızda sempati başlamıştır.

Lütfi Fikri- Evet efendim.

Reşit Galip Bey- Şu halde sizin nokta-i ittihadınız meşrutiyet oluyor.

Lütfi Fikri- Efendim Avrupa'da parlamento hayatı pek gariptir.

Reşit Galip Bey- Bu vakayi Türkiye'de cereyan ediyor, hadise burada iken misaller için daima Avrupa'ya gitmek caiz değildir.

Lütfi Fikri- Bendeniz oradan mülhem olarak bir firkayı ekalliyete düşürebilmek için iki firka birleşebilir fikrini kabul etmiştim. Fransa'da bu çok olur. Fransa'da daha yakın zamanlarda oldu. Fransa'da sosyalistlere karşı merkez fırkaları meşrutiyet taraftarlarıyla ittifak etmişlerdir. Bunlar parlamenter şeylerdir. Daima olur. Belki bendeniz bu şeyden mülhem olarak yazmışım.

Reis- Şu halde Fransa'nın bugünkü vaziyetine nazaran düşünüyorsunuz.

Lütfi Fikri- Evet efendim.

Reis- Fransa'nın cumhuriyete geçtiği zamanı hatırınıza getirseniz inkılabın icabı olarak bugün hiç birinizin yaşamaması lazım gelirdi. Niçin Fransa'nın yalnız bugünkü günü ile mukayese ediyorsunuz.

Lütfi Fikri- Hükümet-i cumhuriyetimiz son asar-1 tekâmül ve terakkiyi gösterecektir.

Reşit Galip Bey- Yine notlarınızda "kaldı ki bizim dört beş aylık vakayi-i dâhiliyemiz ona -yani İngiltere'ye- bir kat daha ümit verecek bir mahiyettedir. Maatteessüf memleket artık müttehid değildir" diyorsunuz. Memleketteki adem-i ittihadın memleket için mahza felaket olacağını pek güzel takdir buyurduğunuz halde firka-i muhalife olarak tanıdığınız bir grubu mütemadi ilhama tenezzüle körüklemek suretiyle..

Lütfi Fikri- Program göndermişimdir efendim, körüklemek değil. O da sulhtan sonra tesis edecek bir firka için.

\footnotetext{
${ }^{49}$ Lütfi Fikri Bey meşrutiyeti ilk olarak 1922 yılında kaleme aldığı “Hükümdarlık Karşısında Milliyet Mes'uliyet ve Tefrîk-i Kuvâ Mesâili" adlı bir risale ile savunmuştur. Bunun arkasından da 25 Eylül 1923 tarihinde de "Meşrutiyet ve Cumhuriyet" adlı risalesini yayımlamıştır.
} 
Reşit Galip Bey- Efendim bir firka-i muhalife vardır. Siz bu firka-i muhalifeye kuvvet vaat ediyorsunuz. Diğer taraftan da diyorsunuz ki: Memleketin vaziyeti muhaliflere tahammül edecek bir mertebede değildir, adem-i ittihat memleket için bir felakettir. Tehlikeli tasavvur ettiğiniz şu vaziyete göre sizden intizar olunurdu ki muhalefeti daha ziyade teşvik edecek bir müdahale değil, muhalefeti ortadan izale ve vahdeti temin edecek bir müdahalede bulunasinız.

Lütfi Fikri- Arz edeyim efendim, bunun emsali çoktur. Çok defa böyle meşrutiyet taraftarları birleşirler. Hatta Fransa'da 40 sene evvel böyle olmuştur. Malum-1 devletleridir ki Almanya orduları Fransa'ya girdikleri vakit meclis Bordo'ya iltica etmiş idi. Bordo'da (Pacte de Bordeaux) diye bir ittifak vardır. Bu ittifak cumhuriyet ve meşrutiyet firkaları arasında olmuştur. $\mathrm{O}$ ittihat şu idi ki...

Reis- Yani onların kral taraftarlarının Prusyalılarla ittifak ederek Fransızları boğmak istediğinin nazariyesi olarak biz de Vahidettin taraftarlarının...

Lütfi Fikri- İstirham ederim efendim, müsaade buyurunuz. Bordo'da cumhuriyet taraftarlarıyla meşrutiyet taraftarlarının (Pacte de Bordeaux) namıyla imza ettikleri bir şey vardır. Bunlar dediler ki şu 23 sene zarfında aramızda katiyen cumhuriyet ve meşrutiyet lakırtısı olmasın. Bir müdafaa-i milliye hükümeti teşekkül etsin ve bu hükümet kat'iyen bu meseleleri mevzu-1 bahs etmesin. Ta ki düşman memleketten çıkar ve biz bize kalırız. O zaman bunları ara-yı umumiyeye arz ederiz. Ve bu suretle yapılmış olan Pacte de Bordeaux iki buçuk sene kadar devam etmiştir. Ve çok hayırlı asar vücuda getirmiştir. Ve o Pacte de Bordeaux dâhilinde Mösyö Tiyer reis-i cumhur olmuştur. Biz bu firkayı hazırlamakla beraber okuduğunuz şeyler dairesinde hükümetten hariç olarak teşekkül eden firkanın hükümeti haiz olan firka ile Pacte de Bordeaux dairesinde, bu meseleleri kat'iyen bahse etmeyelim, selamet-i vatan için şöyle yapalım, böyle çalışalım diye her türlü müzakeratta bulunabilirdi.

Reşit Galip Bey- Sizin en samimi hislerinizin ma'kesi olan defterinizde buyurduğunuz ittihat-1 efkâra müteallik edna mülahaza yoktur.

Lütfi Fikri- Mektuplarımda vardır.

Reşit Galip Bey- İngiltere'nin müşkülat çıkardığını söylediğiniz ve tatbik ettiğiniz bir zamanda siz memleketteki muhalif firkaya daha ziyade bütün müzaheretinizi vererek ittihatsızlığ 1 teşvik ediyorsunuz.

Lütfi Fikri- Efendim bir program göndermişimdir. Eğer bu program kabul edilse idi ve bir cumhuriyet firkası kabul olunsa idi. Bu tesis ettikten sonra firkalar tabii birbirileriyle döğüşmez. Meşrutiyet silahı ile yekdiğerine mukabele ederler.

Reşit Galip Bey- Mademki bu kadar güzel düşünüyorsunuz onları muhalefetlerinde bir nizam ve intizam altına alacak, daha ziyade takviye edecek bir şekil tercih edeceğiniz yerde bir nasihatname gönderebilirdiniz. Eğer onların nezdinde sizin için bir sempati husule gelmiş ise orada diyebilirdiniz ki muhalefetinizi bırakınız, sulh olsun ondan sonra esas üzerinde yürürüz.

Lütfi Fikri- Efendim bu rüşeym halinde kalmış bir şeydir. Belki inkişaf etse idi, Meşrutiyet Fırkasının teşkilinden sonra, bendeniz pekiyi hatırlıyorum. Pacte de Bordeaux hakkında yazılarım vardir.

Reşit Galip Bey- Belki olabilirdi. Fakat bu ihtimalin pek baid olduğu söylenmelidir. 


\section{Lütfi Fikri- Olabilir efendim".}

Müdde-i Umumi Reşit Galip Bey daha sonra konuyu Lütfi Fikri'nin günlüğünde Mustafa Kemal Paşa için kullandığ 1 cümleye getirmiştir. Reşit Galip Bey, Lütfi Fikri’ye günlüğünde Mustafa Kemal Paşa için yazdığı "Zaten daha şimdiden müstakbel, görmeye alışmış gözler için az çok belirir olmaya başladı. Mustafa Kemal Paşa'nın balonu hilafet ve saltanat hakkındaki 2 Teşrinisani tarihli karardan sonra delindi. O vakitten beri sukut ediyor" cümlesini hatırlattıktan sonra bu "sükûtun" hâlâ devam edip etmediğini sormuştur.

Lütfi Fikri'nin buna cevabı "Efendim ben kendi halimde oturuyorum zan ederken üzerinden sakfı alınmış bir adam vaziyetinde kaldım" dedikten sonra şöyle olmuştur: "Bendeniz o vakit saltanat ve hilafeti kaldırmak memlekete bir zaaf getirir fikrinde bulunmuşumdur. Fakat bir emr-i vaki olmuştur. Hatta son iki tevkifim arasında şimdiki ricalden bir kaçı ile Serkl Doryan'da oturuyorduk, orada böyle bahisler oldu. Niçin bu mektubu halifeye yazdın dediler. Ben de, beni onlara mensup birisi mi zan ediyorsunuz. Bu müessesenin içinde altı yüz senedir oturuyorlar, bunları memleketten zor çıkarırız zan ediyordum. Ben onları bir temelin kilit taşı gibi görüyordum. Hatta görüştügümüz zevattan birisi hayır! Bir kanser tümörüdür. Kilit taşı değildir dedi. Bu zevatın ismini de söyleyebilirim: Şükrü Kaya Bey! Temenni ederim öyle olsun dedim, efendim emr-i vakilerinde büyük bir şey vardır. İnkılap olmuş. Çok şükür memleket çökmemiş, kilit taşı olmadığ1 anlaşılmış. İnşallah zat-1 alinizin buyurduğu gibi bir kanser tümörü olduğu tecelli eder dedim. Hatta orada diğer mebus bir zevat da vardı. Temenni ederiz ki böyle olsun dedik. Bendenizin o vakit ki halet-i ruhiyem başkadır, şimdiki halet-i ruhiyem başkadır. Biz ki tekâmülcüyüz diye iddia ediyoruz. Emr-i vakilerin bir şeysi yoktur. Bir şey yapmak ne kadar zorsa yapıllmış bir şeyi iade etmek de o kadar zordur".

Bu cevaptan sonra Reşit Galip Bey, "İttihatçılarla birleşip birleşmeme meselesi benim için de varittir” diyorsunuz. Biraz daha yukarı satırlarda İttihatçılara en meşum rolü veriyorsunuz. Yani Türk tarihinde bütün Türk Milletinden şimdiye kadar kimsenin ihraz edemediği bir mertebe-i muhabbet ve mertebe-i tebcili ihraz etmiş olan bir zatı öldürmek rolünü onlara veriyorsunuz" diye devam edince Lütfi Fikri, "Mütalaa olarak söylüyorum” demiştir.

Reşit Galip Bey, "Bunu yapabilecek adamlardır diyorsunuz ve biraz daha aşağıda "İttihatçılarla birleşip birleşmemek meselesi benim için de variddir” buyuruyorsunuz. Bu kadar meşum efale tasaddi edebilecek bir kabiliyet-i redîede gördüğünüz insanlarla nasıl olup da birleşebilmek tasavvurunda bulunuyorsunuz. Siz ki politika sahasında idealist olarak on beş seneden beri yürümüş olmak iddiasındasınız” diye devam edince Lütfi Fikri’nin buna cevabı şöyle olmuştur:

"Efendim zaten silsile-i kelam da bunu gösteriyor ki bunlar sinema filmi gibi hatırıma gelen şeylerdir, oraya koymuşum. Birinci sahife ile ikinci sahife arasında kat'i bir rabıta olmak lazım gelir. O gün öyle düşünmüşüm yazmışım. Olabilir ki benim gibi meşrutiyetperver bir adamın, öyle her şeyi kanun dairesinde yapmak isteyen bir adamın bunlarla müttefik olması bunlardaki komitecilik hissine izale eder. Bu gibi muhtelif unsurların faidesi yekdiğerine görülmüştür. Yani birbirine faidesi dokunmuştur. Şimdi bir komite olur, bu komite kendi başına kalırsa komiteciliğinde devam eder. Fakat o komitenin yanına sırf kanun dairesinde hareket etmek isteyen bir unsur gelirse o galebe eder. Hatıramın altında bakiyyetü's-süyûfdan bahsediyorum. Belki İttihat ve Terakki ile birleşirsek biz onların arkasından gitmeyiz, onları bizim arkamızda görürüz. Çünkü rüesası gitmiştir. Şimdi rüesa gidip de komitenin idaresi ikinci, üçüncü derecedeki zevata geçince komitenin o kadar kıymeti kalmaz. Bendeniz eğer böyle hala komitecilik peşinde koşanlar ile 
birleşmek istiyorsam, onlarla ittifakı mevzu-1 bahs etmiş isem daha evvel onlarla niçin birleşmemişim. Onlarla daha evvel birleşebilirdim”.

Mahkeme Başkanı, Lütfi Fikri'nin günlüğünde İzmir'deki temaslarından bahsettiği kişinin görüştüğü İttihatçıları sormuştur. Lütfi Fikri, birçok kişi olduğunu ancak hatırına gelmediğini söylemiştir.

Daha sonra Mahkeme Başkanı Lütfi Fikri’ye 1923 yılında hapishanede iken Şeyh Said İsyanı sırasında idam edilmiş olan Kör Sadi ${ }^{50}$ tarafından kendisine gönderilen bir gazeteyi sormuştur: "Hapishanede bulunduğunuz sirada "hapishane-i umumiyede şecaat-1 medeniyenin sarsılmaz kahramanı mahkeme-i İstiklaliyenin ilk kurbanı, vatanın sertac ve ibtihacı ve memleketin öz evladı, hulasa memleketin gözbebeği olan mir-i muhterem Lütfi Fikri Beyefendi Hazretlerine takdim” diye bir gazete gönderilmiş. Bu gazeteyi size memleketin parçalanması için çalışmış ve bugün idam edilmiş bulunan Kör Sadi göndermiş".

Daha sonra yargılama şöyle sürmüştür:

"Lütfi Fikri- Görüyorsunuz ki gazeteyi açmamışım bile.

Kılıç Ali Bey- Hatıra olarak saklamışsındır?

Lütfi Fikri- Efendim o zaman birçokları yazmıştır göndermiştir, yalnız ondan almamışımdır.

Reis- Bu Kör Sadi ile nereden ve nasıl tanışırsın?

Lütfi Fikri- Evvelden hiç tanışmadım. Belki hapishane-i umumiye diğer ziyaretçiler meyanında gelmiştir. Bilmiyorum.

Reis- Şahsen tanımıyorsunuz?

Lütfi Fikri- Kısa boylu, siyah sakallı birisidir zannederim.

Reis- Konuşuyor musunuz?

Lütfi Fikri- Hapishaneye gelmiştir. O vakit ziyaretime bin kişiden fazla geldi. O meyanda belki bu da gelmiştir.

Reis- Siz bu adamı çok iyi tanırsınız. İstanbul'dan düvel-i itilafiye henüz çıkmamıştı. Müdafaai Hukuk Cemiyeti teşkilatı yapılmakta idi. İntihabat istihzaratı da vardı. Bu Kör Sadi ve Askeri $\mathrm{Hoca}^{51}$ bir liste tertip etmişler, listeye zat-1 alinizi de dâhil etmişlerdir. Siz bahusus ki mebusluğu daha ziyade görüşmek ve anlaşmak suretiyle kabul taraftarısınız. Yani siz Askeri Hoca'yı ve Kör Sadi’yi tanırsınız değil mi?

Lütfi Fikri- Mukaddesatım üzerine yemin ederim ki Askeri Hoca’yı tanımam.

\footnotetext{
50 Şeyh Said İsyanı'na karışan Kör Sadi (Abdullah Sadi) Şark İstiklal Mahkemesi'nce idam cezasına çarptırılmış ve Kör Sadi 27 Mayıs 1925 tarihinde Diyarbakır'da idam edilmiştir. Nihal Esen, “Şeyh Sait İsyanında Abdullah Sadi (Kör Sadi)’nin Faaliyetleri ve Yargılanması", Fırat Üniversitesi Harput Uygulama ve Araştırma Merkezi Uluslararası Palu Sempozyumu Bildiriler Kitabı, s. 93-102.

${ }^{51}$ Şeyh Said ayaklanmasını desteklediği gerekçesiyle 27 Mayıs 1925 Diyarbakır İstiklal Mahkemesi tarafından idama mahkûm edilen ve Hoca Askeri lakabıyla anılan Mehmet Askeri hakkında geniş bilgi için bkz. Erol Akcan, "Türkiye Cumhuriyeti'ni Laikleştiren İnkılapların Taşradaki Yansıması: "Hoca Askeri Olayı", Akademik Sosyal Araştırmalar Dergisi, Yıl: 5, Sayı: 59, Kasım 2017, s. 160-176.
} 
Reis- Listeyi görmediniz mi?

Lütfi Fikri- Kat'iyen efendim. Hapishaneye gelenler arasında bu Sadi de gelmiştir zan ederim.

Reis- Burada Askeri Hoca'ya da aynı sualleri sorduk. İsminizi listeye koyduklarını itiraf etti. Ben hatırlıyorum. Müdafaa-i hukuk namzetlerinden 6-7 kişiyi ileri koymuşlardır. Ondan sonra siz, Ali İhsan Paşa, mabeynci bilmem kimlerle beraber ve size sempati gösterdiklerinden bahsettiğiniz İkinci Gruptan bazılarıyla beraber isminizi koydular. Yakinen anladım ki beraber çalışınız, anlaştınız ondan sonra o liste tertip edilmiştir.

Lütfi Fikri- Kat'iyen efendim. Mukaddesatım namına yemin ederim ki listeden haberim yoktur.

Reis- Seyyid Abdülkadir ${ }^{52}$ ile tanışır mısınız?

Lütfi Fikri- Seyyid Abdülkadir'le aramızda ihtilaf vardı. Mesele şudur: Melek Hanımla Suadiye'deki köşkleri için bir ihtilaf hâsıl olmuştu. Bunu Seyyid Abdülkadir eytamdan almış, kendisindeki senetle duvar içindeki bir kısmın kendisine ait olduğunu iddia ediyor. Yani 25-27 dönüm yerine 47 dönüm almak istiyor. O kısmı ise sahib-i evvel Sadi Bey veresesinden Melek Hanım almış. Bunların işleri uzun sürmüş. 3 sene ihtilafta kaldılar. Nihayet iş temyize kadar gitmiş. $\mathrm{Bir}$ gün bendenize geldiler, sizi hakem yapalım, bizim davamızı hal $\mathrm{u}$ fasl ediniz dediler. Bendeniz de vicdanıma ve hukuka istinat ederek davayı Abdülkadir'e kaybettirdim. Ondan dolayı Abdülkadir bana muğber oldu. Evrakı da zannedersem yazıhanemde duruyor.

Reis- Oğulları ile münasebetin?

Lütfi Fikri- Maslup olan oğlu ${ }^{53}$ da bu dava münasebetiyle yazıhaneme gelmiştir.

Reis- Bedirhanilerden Emin Beyle tanışır mısınız?

Lütfi Fikri- 15 sene evvel görmüşümdür.

Reis- Beraber çalıştınız mı?

Lütfi Fikri- Kat'iyen efendim, bendenizin mebusluğum zamanında bir iki defa Meclis Mebusan'a ziyaretime geldi zannederim. Beyaz sakallı bir zat olsa gerektir. Sağ olup olmadığını bile bilmem.

Reis- Kâmuran Ali ve Celadet Ali Beyleri ${ }^{54}$ ?

Lütfi Fikri- Bu isimleri şimdi işitiyorum.

Reis- Bir semtte oturuyorsunuz?

Lütfi Fikri- Affedersiniz beyefendi, şimdi hatırladım. Kâmuran Ali Bey Baroda mukayyet avukattır. Bütün avukatları tanıdığım gibi onu da biraz tanırım. Hatta bendenize karşı hürmetsiz bir mektup yazmıştır. Bendenizden birisinin alacağı varmış, güya bu onun vekâletini alıyor, müekkilim paranın tahsilini bendenize emretmiştir tarzında bir mektup göndermişti. Bendeniz de bir avukat

\footnotetext{
5217 Ekim 1918 tarihinde teşkil kurulan Kürt Teali Cemiyeti'nin başkanı olan Şeyh Abdülkadir, Şeyh Said ayaklanmasını desteklediği gerekçesiyle Diyarbakır İstiklal Mahkemesi'nde yargılanmış ve 27 Mayıs 1925'de idam edilmiştir. Tunaya, age., II, s. 198.

${ }^{53}$ Şeyh Said İsyanında Seyyit Abdülkadir ile beraber oğlu Seyyit Muhammet de idam edilmiştir.

${ }^{54}$ Bu kişiler Bedirhan ailesinden iki kardeştir.
} 
nasıl olur da baro reisine müracaat etmeden haklı haksız olduğunu bilmeden böyle bir mektup nasıl yazılır diye baro meclis-i inzibatına verdim ve ceza verilmesini talep ettim". ${ }^{55}$

Mahkeme Başkanının Lütfi Fikri'ye irtibatının olup olmadığını sorduğu bir kişi de Şerif Paşa ${ }^{56}$ olmuştur. Lütfi Fikri Şerif Paşa'yı ilk defa Cenevre'de gördüğünü ve kendisine barış konferansında Kürtlerin temsilcisi olmasını önerdiğini, ancak bunu kabul etmediğini söylemiştir:

“Lütfi Fikri- Şerif Paşa’yı ilk defa Cenevre'de gördüm. Biz Cenevre'de idik, Şerif Paşa da Paris'ten Cenevre'ye geldi. Oradaki Kürtler tarafından bir grup yapmak istiyor ve o grup namına murahhas olarak Paris'e gitmek istiyordu. Bendeniz ruy-1 iltifat gösterdim. Nazikâne görüştük. Fakat buna taraftar olmadım. Sonra bu Paris'e gitti. Bir gün kendi imzasıyla ve hariciye nezareti vasıtasıyla bendenize bir telgraf gönderiyor. Bendenizi Fransa konsoloshanesine çağırdılar. Elime bir telgraf uzattılar. Açtım, okudum. Şerif Paşa diyor ki Kürt cemiyetleri seni ve beni delege olarak intihap ettiler. Hemen geliniz. Hemen cevap verdim dedim ki bütün Osmanlıları temsil için gelmeyi maatteşekkür kabul ederim. Fakat yalnız Kürtleri temsil için gelmem. ${ }^{57} \mathrm{Bu}$ sonradan zan ederim zat-1 alinizin de bulunduğunuz mecliste mevzu-1 bahs olmuş ve bu telgraf okunarak alkışlanmıştım. Takvim-i Vekayi'de vardır.

Reis- Demek o mesele ile alakanız yoktur?

Lütfi Fikri- Kat'iyen efendim.

Reis- Şimdi bu Sada-yı Íslam gazetesinde Abdullah Sadi ve onun arkadaşları olan Askeri Hoca vesairelerin çıkardığı şu gazetede bir iki ayet vardır. Bu ayetler doğrudan doğruya Tarikat-1 Salahiye'nin alem-i İslam'a karşı istimal ettiği ve serlevha makamında kullandığı ayetlerdir. Dolayısıyla zannediyorum ki sizin Abdullah Sadi ile herhalde daha yakın irtibatınız vardır.

Lütfi Fikri- Hayatım bahasına olsa yalanı kabul etmem efendim. Hilaf-ı hakikat bir şey söylemem. Bendeniz bunu hapishanede beni ziyarete gelenlerden biridir zan ediyorum. Tarihine bakılırsa hapishanede iken bu gazeteyi getirdiği anlaşılır. Fakat yemin ederim ki bu gazeteyi okumamışım ve buyurduğunuz ayeti görmemişimdir. Şimdi zat-1 alilerinden işitiyorum. Oradan yolluyorlar buradan yolluyorlar zat-1 alinize gelmiyor mu efendim. Ne yapayım. Kimisi vesika diye saklar, kimisi yırtar. Bendeniz yırtıp atamam. Kırk senelik mektuplarım çıktı. Bu da bu suretle kalmıştır. Hoca Askeri’yi de hiç hatırlamıyorum. Kat'iyen görüşmemişimdir”.

$\mathrm{Bu}$ diyalogdan sonra Mahkeme Başkanı Ali Bey, Lütfi Fikri’ye gerçek dava konusu olan Tarikat-1 Salahiye'yi sormuştur. Başkan, Lütfi Fikri'ye Mütareke senelerinde İstanbul'da bulunduğu zaman Tarikat-1 Salahiye hakkında bilgisi olup olmadığını sormuştur. Lütfi Fikri'nin buna cevabı net olmuştur. Lütfi Fikri, doğruyu söylediğini tekrarlayıp hayatı bahasına yalanı kabul

\footnotetext{
55 “Lütfi Fikri Bey'in Muhakemesi”, Hakimiyet-i Milliye, 1487, 30 Temmuz 1341, s. 1-2.

56 Kürt Şerif Paşa olarak da bilinen Şerif Paşa'nın hayatı için bkz. Ali Birinci, "Şerif Paşa, Mehmed", Islam Ansiklopedisi, C: 39, Ankara 2010, s. 1-2.

573 Mayıs 1919 tarihli Tasvir-i Efkâr'da Lütfi Fikri'nin sulh konferansında Kürtlerin hukukunu koruyacağı yazmaktadır ("Lütfi Fikri Bey Sulh Konferansında", Tasvir-i Efkâr, 3 Mayıs 1335). 4 Haziran 1919 tarihli Tasvir-i Efkâr'ın haberine göre ise o tarihlerde Cenevre'de bulunan Lütfi Fikri Bey İstanbul'da bulunan bir arkadaşına mektup göndererek bunu kabul etmediğini söylemiştir. Lütfi Fikri mektubunda, Şerif Paşa ile beraber konferansa Kürt murahhası tayin edildiğini, fakat bu teklifi yalnız Kürtlerin değil ancak bütün Osmanlıların hukukunu müdafaa etmek şartıyla kabule hazır olduğunu bildirdiğini ifade etmiştir. "Lütfi Fikri Bey”, Tasvir-i Efkâr, 4 Haziran 1337, s. 2.
} 
edemeyeceğini belirttikten sonra Tarikat-1 Salahiye'yi gazetelerde ismini görünce öğrendiğini, haberi olsa da girmeyeceğini söylemiştir.

Daha sonra Başkan, Kiraz Ahmet'in evine gidip gitmediğini sormuştur. Lütfi Fikri, gitmediğini, sadece vapurda gördüğünü söyledikten sonra "Hayır efendim, vapurda görürdüm. Müdde-i umumi beyefendiye de arz ettim, bendeniz bu tarikata girmek şöyle dursun Tarikat-1 Salahiye'yi bildiğime dair bir kaydım çıkarsa Tarikat-1 Salahiye'ye girmiş gibi cezama razıyım” diyerek Tarikat-1 Salahiye ile bir ilgisinin olmadığını tekrarlamıştır.

Reşit Galip Bey, Tarikat-1 Salahiyecilerin de meşrutiyet taraftarı olduğunu belirtince, Lütfi Fikri buna şöyle mukabele etmiştir: "Onların meşrutiyet taraftarı olmasıyla bendenizin de mutlaka dâhil olmam mı icap eder. Meşrutiyeti meşruiyet silahıyla almak isteyen var. Bir de komite ile almak isteyen vardır. Bendenizin 17 senelik hayatım bütün beyanatımın doğru olduğuna kâfildir. Bendenizde komitecilik yoktur efendim. Komite işi yapamam. Bendeniz meşru bir silah ile uğraşmayı ister ve memlekette bu silahın tesisini arzu eden bir hakirim".

$\mathrm{Bu}$ konuşmalardan sonra sıra abisi Münci Bey'in Lütfi Fikri'ye yazdığı mektuba gelmiş̧tir. Mahkeme Başkanı, iki kardeş arasında memleket hakkında önemli bir sır olduğunu söyleyince, Lütfi Fikri Bey, "Müsaade buyurunuz efendim, aramızda kat'iyen bir sır olamaz" demiştir. Bunun üzerine Başkan, "İcap ederse mektubu okurum. Size bir işaret veriyor. Sizin harb-i umumi esnasında meçhul bir makam veya bir devletle anlaşarak gazete çıkaracağınız anlaşılıyor. "İstanbul'a gidiniz ve evvelce Londra'da tasavvur ettiğiniz gazete işinden istifade ediniz" diyor. Aranızda düşünülmüş konuşulmuş bu gazete çıkarmak meselesi ne idi?" diye devam etmiştir. Bunun üzerine müdde-i umumi araya girerek Başkana hitaben, "meselenin mahiyeti çok mühimdir. Tarihi bir muhakeme icra edilmektedir. Heyet-i celilerinden istirham ediyorum mektup aynen okunsun" demiştir.

Mahkeme Başkanı Ali Bey de "Mektup okunsun da beyefendilerin şahsiyetleri hakkında millet de tenevvür etsin" diyerek müdde-i umumiyi desteklemiştir. Lütfi Fikri, "Mektup okunsun efendim, bendeniz böyle bir şey olmadığına kaniyim. Yalnız aile mektubudur. Hususi bir mektuptur. İstirham ederim. Mühim noktalar okunsun" deyince Başkan, "Fakat mektup aile mektubu olmakla beraber umumiyetle memleket meselesi ile alakadardır. Yani kardeşin ne görüyor, nasıl görüyor anlaşılsın" diye karşılık vermiştir. Neticede özel ve ailevi kısımlar atlanarak mektup okunmuştur.

Mektupta Lütfi Fikri'nin kişiliğine yönelik ağır ifadeler kullanan abisi Münci Bey, yine ağır ifadelerle Lütfi Fikri'nin para taleplerinden olan rahatsızlığını dile getirmiştir. Daha sonra Münci Bey, Lütfi Fikri'ye vakit geçirmeden İstanbul'a gitme tavsiyesinde bulunmuştur. Tevfik Paşa Hükümetinden sonra hükümeti kim teşkil ederse ve kendisini davet ederse hemen kabul etmesini ve hükümet üyelerine fikirlerini ve programını kabul ettirmesini, bu şekilde sadrazam olduktan sonra da Almanya'ya firar eden İttihatçıları İngilizlere teslim ettirmesini istemiştir.

Münci Bey’e göre ülkeyi kurtaracak tek yol “İngiltere'nin taht-1 himayesine” girmekti: “Sulhtan sonra beş senelik ömrümüz kalmadı. Biraz sadaka şeklinde bırakılacak vilayatı bile beş sene içinde elimizden alacaklar! Bunun önünü ne bu hanedan-1 saltanat alır, ne de senin bayıldığın Sabahattin!.. Bizi bir şey kurtarır o da hemen İngiltere'nin taht-1 himayesine girmek Mısır ülkesi gibi bir şey olmak".

Münci Bey, Lütfi Fikri'nin barıştan sonra elde kalacak dört beş vilayeti iyi idare etmesi ve milletin karnını doyurup ve asayişi temin etmesi durumunda Türkiye'de büyük bir hürmet 
göreceğini belirttikten sonra İkinci Meşrutiyet dönemindeki gibi Tanzimat gibi bir gazete çıkararak kimseyle tartışmaya girmemesini de tavsiye etmiştir. Bu arada telgraf hakkında bilgi vermemekle beraber "tanımadığım Suphi Bey'in telgrafını leffen iade ediyorum" diye yazmıștır.

Münci Bey bu tavsiyelerde bulunduktan sonra şartını kabul ederse beş bin frank para yollayacağını ifade etmiştir. Münci Bey'in Lütfi Fikri'ye şartı, vergilerden muaf olabilmek için fahri olarak Londra başşehbenderliğine tayin edilmesine yardımcı olmasıydı: "Evvelce de sana yahut Zahide'ye yazdığım veçhile devlet memuriyetinde zerre kadar gözüm yok. Ticaret kadar tatlı, hiçbir şey olamaz. Ancak İngiltere ve Paris'ten aldığım malumata göre, bu memalikte harp ilcasıyla vergiler yüzde elli artmış, gelir vergisi yüzde altmışı bulmuş! Badelharp bu memlekette ne işe girsem kazancımın yarısı hükümetlere vergi olarak vermeye mecbur olacağım. Hâlbuki bir devlet memuru olsam bu vergilerden masun kalırım!

Memuriyette gözüm olsa bir sefirlik isterim. Hâlbuki öyle bir emelim yok. Fakat bu vergilerin tezayüdü ilcasıyla tekrar Londra başşehbenderliğine gitmek isterim. O zaman vergi vermeye mecbur olmam. Hariciye Nazırı Nabi Bey pek aziz dostumdur, hükümetin benden şikâyeti yoktur. Nezaretçe de zerre kadar mevkiime halel gelmemiştir. Bunu Nabi Bey de bilir. Binaenaleyh fahri olarak Londra başşehbenderliğine, İstanbul'a varır varmaz beni tayin ettirsen, hakkımı ödemiş olursun. Fahri memur olursam ticaretime hükümet mani olamaz. Kaldı ki hükümetin mezayıka-i maliyesi ilcasıyla ba'del harp birçok şehbenderleri bulunamaz. İktisat ve tasarruf lazım. Bir de şu var: Fahri bir memuriyete kimse talip olamaz. Bana eski memuriyetimi kimse çok görmez. Çünkü Londra benim son memuriyetim idi. (Ba'del harp İstanbul'a avdet etmeyen memurin-i hariciye bir aya kadar İstanbul'a gelmeyecek olurlarsa azledileceklerdir) kararı üzerine birkaç kişi ile beraber benimde uhdemden Londra başşehbenderliği alınmış idi. Tevfik Paşa beni sever. Nabi dostumdur. Sen onlara söyleyecek olur ve ısrar edip gözünün önünde inhanameyi yazdırırsan sulhun imzasını müteakip ben de kalkar buradan memur olarak Londra'ya giderim. Sefirlik mefirlik falan da gözüm yok, anladın mı? Eğer bana bunu kat'iyen vaat eder ve bütün kuvvetinle çalışıp muvaffak olacağını temin edersen ben de senin bütün kusurlarını affederim. Kaldı ki nezarette en büyük düşmanım Umur-1 İdariye Müdürü Suat Bey, İttihat ve Terakki'nin sukutu üzerine ya nezaretten gitmiştir yahut nüfuzu olamaz. Bunu bana vaat ediyor musun? Söz verir misin? Taahhüdatı havi taahhütlü mektuba muntazırım. Sen de gidecek yolu bul. Fakat zan etmiyorum ki kolay kolay yollar açılmış olsun. Bana kalırsa (burası mahramane) sen orada İngiltere sefiriyle görüşmelisin. Kablel-harp Londra'daki mahut gazete işinden, senin muhalifin partisi rüesasından olduğundan bahsederek Yunanistan tarikiyle İstanbul'a duhulünü rica etmelisin zan edersem reddetmezler". ${ }^{58}$

Mektubun okunmasından sonra yargılama şöyle devam etmiştir:

"Lütfi Fikri- Hayatımı sefalet içinde geçirdiğim görülüyor efendim. Sonra oradaki Suphi Soysallığlu Ali Suphi Bey’dir. Bana bir kart yazdı. İttihatçılar kaçtı ortalık şöyle kaldı böyle kaldı, siz de memleketin maruf adamısınız, binaenaleyh ne duruyorsunuz. Demin arz etmiştim. Harcırah göndersin de gidelim diye yazmıştım. Sonra efendim biraderim beni Sabahattin'e fazla merbut zan ediyor. Teessürle yazılmış, aksi fikirde olduğumu biliyor. İtiraz ediyor. Bendenizin Tanzimat isminde bir gazetem vard1.

Reis- İngiliz sefiriyle görüştünüz mü, size görüşmenizi tavsiye ediyor?

58 Münci Bey'in mektubu yüzünden gazetelerde Lütfi Fikri ve ailesine karşı ağır ifadeler kullanılmıştır. Bkz. Ağaoğlu Ahmet, "Bu Nasıl Aile", Hakimiyet-i Milliye, 30 Temmuz 1341, s. 1; "Bu Nasıl Aile”, Cumhuriyet, 1 Ağustos 1341, s. 1. 
Lütfi Fikri- Hayır efendim. Avusturya veliahdı ve zevcesi katledildiği ve harb-i umumi başladığ 1 zaman bendeniz Viyana'da idim. İstanbul'da zaten menkub olarak Ayastefanos'ta oturuyordum. Sonra Avrupa'ya gitmiş̧tim. Harb-i umumi başladığı zaman her taraf kapandı. Vaktiyle Mısır'da avukatlık yapmıştım, gideyim yine orada avukatlık yapayım dedim. Bendeniz harb-i umumiye taraftar değildim. Mısır'da hem avukatllk etmek, hem de bir gazete çıkarmak istiyordum. Gazetemle bi-taraf kalmaklığımızı müdafaa edecektim. Sonra bitaraf kalmamız İngiltere'nin arzu ettiği bir şey idi. Bu suretle Mısır'da barınabilecektim. Bendenizin evvelce Mısır'da avukatlık yapıp da İstanbul'a dönmem arasında altı sene geçmişti. Bu müddet zarfinda Mısır hükümeti birçok şeyleri değiştirmişler, bir takım ikamet kayıtları, birçok müşkülat vardı. Kalktım Viyana'dan Mısır'a gittim. Fakat Mısır hükümeti gazete çıkarmama kat'iyen müsaade etmedi. Her ne olursa olsun Türkiye'ye dair gazete çıkarmanıza taraftar değiliz ve müsaade edemeyiz. Gerek lehimize gerek aleyhimize dair hiçbir yazı istemiyoruz. Biz Türkiye ile dost geçinmek istiyoruz falan dediler.

Reis- O sırada harp başladı mı idi?

Lütfi Fikri- Biz daha bitaraf idik. Ondan sonra avukatlığı da zor gördüm. Korktum. Dediler ki boğazların kapanmak tehlikeleri falan vardır. Kardeşim Londra'dadır. İstanbul'a gitmek için müşkülat var. Londra'ya gitmek daha kolay idi. O vakit vapurlar işliyordu. Mısır'dan kalktım Londra'ya biraderimin yanına gittim. O vakit İngilizlerle aramız iyi idi. Bendeniz Londra'da kalacaktım. Biz de henüz bitaraf idik. Ben de bitaraf kalmamız hakkındaki fikirlerimi Mısır'dan Londra'ya gidince kendisine söylemiştim. Onları hatırlıyor ve diyor ki İngiliz sefirini görürsen dersin ki ben harb-i umumiye memleketimizin girmesine taraftar değilim. Hatta bunun için Misır'da bir gazete çıkarmak istedim. Fakat Mısır hükümeti müsaade etmedi. Bunlar onların nazarında senin için emniyetbahş bir şey olur. Sana müsaade ederler diyor. Maksadı budur. Bendeniz Londra'da harbe iştirak ettiğimiz zamana kadar kaldım. Fakat vakta ki harbe iştirak ettik. Türk vatandaşı olarak memleketimize dönmemiz lazımdır. Bizim için artık şu veya bu vaziyet yoktur dedim. Tevfik Paşa ile beraber çıktık. İngilizler oradaki sefirimize ileri gelenlerden Türk tebaasından kırk kişi kadar beraber götürmesine müsaade etmişlerdi. Bendenizde bu suretle Tevfik Paşa ile çıkmışımdır. Telmih ettiği şey budur. Sonra onun bendenize olan tevcihatı kendi kendinedir. Bunda benim bir kabahatim yoktur.

Reis- Şimdi bunu uzun boylu tahlil etmeyi muvafik görmüyoruz. Münci Bey mebus Feridun Fikri Bey'in babası değil midir?

Lütfi Fikri- Evet efendim".

Mahkeme Başkanı daha sonra Münci Bey ile ilgili başka bir iddiayı sormuştur: "Anlamak isteriz. $\mathrm{Bu}$ da meçhul bir meseledir. Ve sizin az çok malumatınız olması lazım gelir. Bunun üzerinde 350 bin lira altın para kalmışır".

Lütfi Fikri buna, "Bendeniz onu başkalarından daha fazla bilmiyorum. Belki mektubun bir tarafinda var. Bu para Yemen'e gidecekmiş" şeklinde cevap vermiştir. Bu cevap sonrası Mahkeme Başkanı Ali Bey, "Yani Hakkı Paşa merhum Münci Bey’e 350 bin altın lira vermiş. O da 50 bin lirasını şu veya bu vasıtaya verecek" diye devam edince Lütfi Fikri Bey konuyu şöyle açıklamıştır: "Lahey'den bendenize Cenevre'ye yazdığı mektuplardan birisinde paranın vusul bulmadığını ve binaenaleyh benim ketmettiğimi, sirkat ettiğimi zan etmişler diyor ve çok şükür paranın yerine vasıl olduğunu- veyahut iade edildiğini- kaydediyordu. Bunu zat-1 devletleri için tahkik etmek kolaydır. Biraderimin bendenize gösterdiği şiddetlere rağmen ben onun daima temiz kalmasını isterim. Zan 
ederim ki o meselede biraderim beraat etmiştir. O zaman hükümet parayı doğrudan doğruya gönderemiyordu. Hollandalılar vasıtasıyla göndermek esbabına tevessül etmişti. Para vusul bulmuş mudur, yoksa iade edilmiş midir, nedir, pekiyi bilemiyorum. Biraderim de bunda beraat etmiştir. Bu mesele hakkında hariciye vekâletinin lüzumu kadar malumatı vardır zan ederim”.

$\mathrm{Bu}$ konuşmalardan sonra Mahkeme Başkanı yargılamanın yeterli olduğunu söylemiştir. Bunun üzerine Lütfi Fikri, "İstirham ediyorum, efendim. Kırk beş günden ziyade mevkufum" diye durumunu arz edince Başkan "Vaziyetinizi mütalaa ederek arkadaşlarla bir karar vereceğiz" diyerek mahkemeyi bitirmiştir. ${ }^{59}$

\section{Mahkemenin Kararı}

Tarikat-1 Salahiye davasında yargılananlar hakkındaki iddianame 8 Ağustos 1925 tarihinde hükümet binasının altındaki Asliye Ceza Mahkemesi salonunda okunmuştur. Savcı birçok kişiyi vatana ihanetle suçlamış, bazı kişilerin ise beraatını talep etmiştir. Lütfi Fikri hakkında ise "Lütfi Fikri Bey Tarikatı Salahiye ile alakadar olarak dâhil-i dava edilmiştir. Fakat alakasına delalet edecek bir emare bulunamamıştır. Üzerinde ve evinde zuhur edip efkâr-1 umumiyeye neşredilen vesaik ise kendisinin meşrutiyetperver ve padişaha taraftar olduğunu isbat etmektedir. Fakat Lütfi Fikri Bey bunları neşretmediği cihetle kanunen mücrim addedilemez" demiş̧ir. Mahkeme Başkanı, maznunlara müdafaalarını yazmak üzere Salı gününe kadar müsaade edileceğini söyleyerek mahkemeyi bitirmiştir. ${ }^{60}$

Lütfi Fikri Bey 11 Ağustos'taki müdafaasında, TBMM tarafindan 1924 y1lında affedilmesinden ${ }^{61}$ sonra kesinlikle siyasetle iştigal etmediğini, Tarikatı Salahiye'ye mensubiyeti olmadığ1 gibi ismini de mahkemede işittiğini belirttikten sonra müdde-i umuminin talebi doğrultusunda mahkemenin de beraatına karar vermesini istemiştir. ${ }^{62}$

Neticede 15 Ağustos 1925 tarihinde karar açıklanmıştır. Davada birçok kişi beraat etmiş, on bir kişi ise idama mahkûm olmuştur. İdama mahkûm olanlar 16 Ağustos 1925 tarihinde Taşhan önünde idam edilmiştir. ${ }^{63}$

Beraat edenler arasında Lütfi Fikri Bey de yer almıştır. Lütfi Fikri Bey'in beraat etmesinde cemiyetle bir bağlantısının tespit edilememesi yanında Mustafa Kemal Paşa'nın mektubu da etkili olmuştur. Mustafa Kemal Paşa, karardan bir gün önce 15 Ağustos'ta Mahkemeye gönderdiği mektupta, Lütfi Fikri Bey'in mahkemesini gazetelerden takip ettiğini, mahkemece tespit edilmiş başka bir konuda "kanuni esbab-1 ithamiye" yoksa şahsıyla ilgili fikirlerinden dolayı Lütfi Fikri'nin cezalandırılmamasını rica etmiştir:

"İstiklal Mahkemesi Riyaset-i Aliyesine, İstiklal Mahkemesine mevdu olanlar meyanında Lütfi Fikri Bey'in safahat-1 mahkemesini gazetelerde mütalaa eyledim. Mumaileyhin efkârımız ve hatta hatt-1 hareketlerimizden esas itibariyle farklı olan bir takım mülahazat ve tenkidata bu vesile ile muttali oldum. Kanuni yollarla milletin tezahür eden irade-i kat'iyesi, teşkilat-1 devlet ve usul-1 idare hakkında Lütfi Fikri Bey'in efkâr-1 hususiyesine tevafuk etmeyen tecelliyat-i nihaiyesini

\footnotetext{
59 "Lütfi Fikri Bey'in Muhakemesi”, Hâkimiyet-i Milliye, 1488, 31 Temmuz 1341, s. 1-2.

60 "Tarikat-ı Salahiyecilerin Hakkındaki Iddianame", Cumhuriyet, 449, 9 Ağustos 1925, s. 2.

61 Lütfi Fikri, 13 Şubat 1924 tarihinde TBMM tarafından çıkarılan 124 sayılı özel bir yasa ile affedilmiştir. TBMM Zabıt Ceridesi, Devre: 2, İçtima Senesi; 1, C: 5, 802.

62 "Tarikat-ı Salahiyeciler Müdafaalarını Verdiler", Cumhuriyet, 12 Ağustos 1925, s. 2.

63 "Dünkü Idamlar", Hâkimiyet-i Milliye, 1502, 17 Ağustos 1341, s. 1.
} 
göstermiştir. Şahsımın bertaraf edilmesi tahminatına ve bu tahminatın neticesi olmak üzere derpiş ettiği tasavvurata karşı mahiyet-i hukukiyesi müsaid dahi olsa şahsen bir iddia dermeyan etmeye mütemayil değilim. Binaenaleyh gerek efkâr-1 siyasiyemize ve gerek şahsımıza karşı olan vaziyetinden dolayı -eğer âli mahkemece başka zeminde kanuni esbab-1 ithamiye mevcut değilsemahkeme-i alilerinin müsamahasını isticlab ediyorum. Reis-i Cumhur Gazi Mustafa Kemal". ${ }^{64}$ Mustafa Kemal Paşa'nın mektubu mahkemede aynen okunmuştur. ${ }^{65}$

Lütfi Fikri hakkında açıklanan kararda, Tarikat-1 Salahiye ile ilişkisinin tespit edilemediği, evinde yapılan aramalarda ortaya çıkan evraklardan dolayı ayrıca mahkemesi gerekiyorsa da, Cumhurbaşkanı Mustafa Kemal Paşa'nın bu konudaki şahsi hukuklarından feragat etmesi nedeniyle beraatına karar verildiği açıklanmıştır. ${ }^{66}$ Lütfi Fikri Bey'in beraat kararı ile Mustafa Kemal Paşa'nın ricası gazetelerde yan yana yayınlanmıştır.

Lütfi Fikri Bey, beraatı sonrası Mahkeme Başkanı Ali Bey’e giderek teşekkür etmiş̧tir. Bunun yanında Lütfi Fikri Bey, Mustafa Kemal Paşa ve İsmet Paşa'ya teşekkür edebilmek için Ali Bey'den aracılık yapmasını da talep etmiştir. ${ }^{67}$

Hızlı gelişen olaylar Lütfi Fikri Bey’i epeyce yormuştur. Lütfi Fikri Bey, bu tarihten sonra mümkün olduğunca siyasetten uzak durmaya çalışmış ve Galata'daki Yakut Han'da gerçek mesleği olan avukatlıkla uğraşmaya başlamıştır. Ayrıca 1920 yılında seçildiği İstanbul Baro Reisliği’ni beş yıl başarıyla yürütmüştür. Kansere yakalanan Lütfi Fikri Bey, tedavi olmak için gittiği Paris'te 7 Ekim 1934 tarihinde vefat etmiş̧ir. ${ }^{68}$

\section{Sonuç}

Türk Siyasi hayatının önemli ve ilginç isimlerinden biri olan Lütfi Fikri Bey, siyasi hayatının neredeyse her döneminde muhalefet safında yer almıştır. Sultan II. Abdülhamit'e karşı İttihat ve Terakki'nin yanında yer almıştır. 1908'de İttihat ve Terakki iktidara geldikten sonra da İttihatçıların karşısında yer almış ve Mutedil Hürriyetperveran ve Hürriyet ve İtilaf Fırkalarının kurucuları arasında yer almıştır. 1912 yılında Hürriyet ve İtilaf Fırkasından da ayrılarak kendi bir firka kurmak istemiş, ancak Bab-1 Ali Baskını olunca bunu başaramamıştır. Birinci Dünya Savaşı sırasında yurt dışına çıkan Lütfi Fikri savaş bitiminde yurda dönmüştür.

Milli Mücadele ve sonrasında Lütfi Fikri'nin Ankara ile arası hiç iyi olmamıştır. 1920 yılında Müsalemet İtifakı adında bir cemiyet kurarak İstanbul ile Ankara'yı uzlaştırmaya çalışmıştır. Ancak bundaki amacının hafifletilmiş bir Sevr Antlaşmasını Ankara'ya kabul ettirmek olarak görüldüğ̈ için iyi niyetli bir girişim olarak değerlendirilmemiştir. Bunun yanında Lütfi Fikri, Meclis hükümeti sistemine de karşı çıkmıştır. Büyük Millet Meclisi Hükûmeti’nde yasama, yürütme ve yargı kuvvetlerinin bir mecliste toplanması neticesinde kontrolün kaybolduğunu iddia etmiş ve bu sisteme karşı meşrutiyet ve kuvvetlerin ayrılmasını savunmuştur.

\footnotetext{
64 “Reis-i Cumhur Hazretlerinin Ulüvv-i Cenabları”, Hâkimiyet-i Milliye, 1501, 16 Ağustos 1341, s.1.

${ }^{65}$ Cumhuriyet mektubun okunduğu zamanki durumu şöyle aktarmıştır: "Lütfi Fikri Bey hakkındaki satırları ve bilhassa Gazi'nin tezkeresi okunduğu sırada halkın dikkat ve alakası en yüksek dereceyi buldu", Cumhuriyet, 456, 16 Ağustos 1925, s. 1-2.

66 “Tarikat-ı Salahiyeciler Hakkındaki Hükümler", Hâkimiyet-i Milliye, 1501, 16 Ağustos 1341, s. 1-2; Cumhuriyet, 456, 16 Ağustos 1925, s. 1-2.

${ }^{67}$ Cumhuriyet, 457, 17 Ağustos 1925, s. 1.

68 Gazel, Lütfi Fikri'nin Tanzimatı'ı, s. 20.
} 
Lütfi Fikri en sert muhalefeti Halifeliğin kaldırılma sürecinde yapmıştır. Lütfi Fikri, "hilafet ecdad-1 uzmamızın azim ve himmetleriyle Türklüğe kazanılmış bir kuvvettir, bir hazine-i maneviyedir" dediği Hilafetin kaldırılmasını Türklük için bir intihar olarak görmüş, ayrıca, istifa edeceği söyleyen Halife Abdülmecit Efendi'ye "ölüm tehlikesi olsa bile mevkiini, asla terk etmemesini” öğütlemiştir. Lütfi Fikri bu görüşlerine karşı çıkan Necmeddin Sadak’ı da ağır bir şekilde eleştirince İstanbul İstiklal Mahkemesi'nde yargılanmıştır. 27 Aralık 1923 tarihinde beş yıl ağır hapse mahkûm edilmiştir. Ancak Lütfi Fikri, 13 Şubat 1924 tarihinde TBMM tarafindan çıkarılan özel bir yasa ile affedilmiştir.

Lütfi Fikri, 1925 y1lında Ankara İstiklal Mahkemesi'ne sevk edilmiştir. Bu seferki suçlama İlayı Vatan Cemiyeti'nin perde arkasındaki örgütü olarak nitelendirilen ve gizli cemiyet olan Tarikat1 Salahiye'ye üye olmaktır.

Aslında Lütfi Fikri'nin cemiyetle tam bir bağlantısı tespit edilememiştir. Mahkemede bazı kişilerin adını vermesi ve cemiyet üyelerince 1922 yılında yapılan bir kabine listesinde yer almış olmasından dolayı 6 Haziran 1925 tarihinde evinde arama yapılmıştır. Arama sırasında cemiyetle bağlantısını gösterecek bir delil bulunamazken, abisi Münci Bey'in yazdığı bir mektup ve 1923 yılına ait günlüğü bulunmuştur. Özellikle günlüğünde Cumhuriyete, rejime ve Mustafa Kemal Paşa'ya yönelik bazı ağır ithamlar tespit edilmiştir. Lütfi Fikri Bey evinin aranması sonrası önce kefaletle serbest bırakılmasına rağmen yukarda belirtilen mektup ve günlüğ̈ yüzünden tutuklanarak İstiklal Mahkemesi'nde yargilanmak üzere 23 Haziran 1925'te Ankara'ya getirilmiştir. Lütfi Fikri'nin mahkemesi Ankara'ya gelmesinden bir ay sonra 26 Temmuz 1925'te başlamıştır.

Lütfi Fikri mahkemeye Tarikat-1 Salahiye'ye üye olmak suçuyla gelse de, bu cemiyetle tam bir bağlantısı tespit edilemediği için aslında bundan değil, 1908 yılından itibaren tüm siyasi geçmişinden yargılanmıştır. Mahkeme Lütfi Fikri'nin, 1908 yılında İttihat ve Terakki'ye muhalefeti, gazetesinde Arnavut ve Rum ayrılıkçılara yer vermesi, Hürriyet ve İtilafçılarla birlikte olması, 1919 yılında mebusluktan istifa etmesi, 1920 yılında Ankara ile İstanbul'u uzlaştırmak için Müsalemet İttifakı'nı kurması ve Ankara'ya karşı İstanbul'u savunması gibi doğrudan dava konusuyla ilgisi olmayan meselelerden sorgulamıştır. Ancak Lütfi Fikri Bey'in en çok cumhuriyete karşı meşrutiyeti tercih etmesi gündeme getirilmiştir. Zira Lütfi Fikri Bey Cumhuriyetin ilanından sonra bile meşrutiyeti savunmaya devam etmiştir. Lütfi Fikri Bey Cumhuriyetin ilanından yaklaşık iki hafta sonra yazdığg makalede, Halifelikle, milli egemenliği bir arada tutabilecek tek yönetim şeklinin meşrutiyet olduğunu, bu nedenle meşruti idareyi tercih ettiğini ifade etmiştir. ${ }^{69}$

Bunların yanından Lütfi Fikri, esas olarak mahkeme heyetinin de belirttiği gibi evinin aranması sırasından ortaya çıkan günlüklerinden ve abisi Münci Bey'in mektubundan dolayı yargılanmıştır. Günlüğünde 1923 yılına ait yazdıklarında Cumhuriyete ve özellikle de Mustafa Kemal Paşa'ya yönelik ağır ithamlar tespit edilmiştir. Günlüklerine göre Lütfi Fikri Meclisteki İkinci Gruba bir parti programı göndererek onlarla işbirliği yapmaya çalışmıştır. Mustafa Kemal Paşa ile

\footnotetext{
69 Lütfi Fikri Bey Cumhuriyetin ilanından yaklaşık iki hafta sonra 15 Kasım 1923 tarihinde yazdığı makalede Halifelikle, milli egemenliği bir arada tutabilecek tek yönetim şeklinin meşrutiyet olduğunu, bu nedenle meşruti idareyi tercih ettiğini açıkça ifade etmiştir: "Bize hem Hilafeti muhafaza ettirebilecek ve hem hâkimiyet-i milliyeyi emniyette bulunduracak olan meşrutiyet-i idareyi tercih ediyorum." Lütfi Fikri, "Lütfi Fikri Bey Meşrutiyet Taraftarı!", Akşam 1834, 15 Teşrini-i sani 1339 , s. 3.
} 
İttihatçıların birbirlerini yıpratacağını düşünen Lütfi Fikri, aradan sıyrılarak meşrutiyetçi bir parti kurmayı ve iktidara gelmeyi planlamıştır.

Lütfi Fikri "Buyurduğunuz hatıraların mesuliyet-i maneviyesini kabule hazırım çünkü yazmışımdır. Bunlar benim eserlerimdir. Fakat şu elinizdeki hatıralar ilk defa polis marifetiyle güneş görmüştür. Benim harim-i dimağımdır. Bu benim kafamdır. Yani kafamdaki tefekkürat ile o sahifelere geçmiş sözler arasında hiçbir fark yoktur" diyerek bunları yazdığını kabul etmekle beraber eyleme geçmeyen düşünceleri olduğunu, bu nedenle cezalandırılmaması gerektiğini savunmuştur. Mahkeme Başkanının buna cevabı "Biz sizi aynı zamanda manevi muhakeme karşısinda bulunduruyoruz" şeklinde olmuştur.

Lütfi Fikri Bey 11 Ağustos'taki müdafaasında ise TBMM tarafindan 1924 y1lında affedilmesinden sonra kesinlikle siyasetle iştigal etmediğini, Tarikatı Salahiye'ye mensubiyeti olmadığ1 gibi ismini de mahkemede işittiğini, müdde-i umuminin talebi doğrultusunda mahkemenin de beraatına karar vermesini istemiştir.

Neticede 15 Ağustos 1925 tarihinde karar açıklanmıştır. Davada birçok kişi beraat etmiş, on bir kişi ise idama mahkûm olmuştur. Beraat edenler arasında Lütfi Fikri Bey de yer almıştır. Lütfi Fikri Bey'in beraat etmesinde cemiyetle bir bağlantısının tespit edilememesi yanında Mustafa Kemal Paşa'nın mektubu da etkili olmuştur. Mustafa Kemal Paşa, karardan bir gün önce 15 Ağustos’ta Mahkemeye gönderdiği mektupta Lütfi Fikri Bey'in mahkemesini gazetelerden takip ettiğini, mahkemece tespit edilmiş başka bir konuda "kanuni esbab-1 ithamiye" yoksa şahsıyla ilgili fikirlerinden dolayı Lütfi Fikri'nin cezalandırılmamasını rica etmiş̧ir.

Lütfi Fikri hakkında açıklanan kararda, Tarikat-1 Salahiye ile ilişkisinin tespit edilemediği, evinde yapılan aramalarda ortaya çıkan evraklardan dolayı ayrıca mahkemesi gerekiyorsa da, Cumhurbaşkanı Mustafa Kemal Paşa'nın bu konudaki şahsi hukuklarından feragat etmesi nedeniyle beraatına karar verildiği açıklanmıştır.

Davada en çok dikkat çeken konu Lütfi Fikri'nin 1923 yllında firsattan istifade meşrutiyetçi bir furka kurarak iktidara gelmek istemesi olmuştur. Bu Lütfi Fikri Bey için yeni bir şey değildir. Lütfi Fikri'nin siyasi hayatına bakılırsa en büyük arzusu iktidara gelmektir. Bunun için hiçbir firsatı kaçırmamıştır. Ancak Lütfi Fikri iktidara gelmek için kanun dışı yollara sapmamıştır. İktidara siyasi parti kurarak meşru ve kanuni yollarla gelmeye çalışmış̧ır. Bu durumunu dava sırasında da dile getirmiştir: "Bendenizde komitecilik yoktur efendim. Komite işi yapamam. Bendeniz meşru bir silah ile uğraşmayı ister ve memlekette bu silahın tesisini arzu eden bir hakirim".

Lütfi Fikri Bey, bütün siyasi hayatı boyunca muhalefetine ve iktidara gelmek için yaptı̆̆ faaliyetlerine rağmen, ilmi ve yapıcı bir muhalefet yaptığına inanıldığı için hemen hemen her dönemde bu tavrı hoşgörüyle karşılanmıştır. İttihatçılara karşı sert muhalefetine rağmen zaman zaman kendisine nazırlık önerilmiş, Birinci Dünya Savaşı sırasında da yine İttihatçılar tarafından yurt dışına çıkmasına izin verilmiş̧ir. Halifeliğin kaldırılmasına karşı çıkmasına, cumhuriyete karşı meşrutiyeti savunmasına, hatta günlüğünde aleyhinde ağır yazılar yazmasına rağmen Mustafa Kemal Paşa, Lütfi Fikri İstiklal Mahkemelerinde yargılanırken devreye girmiş ve ceza almamasını sağlamıştır.

Bütün bunlara karşın 1925 yılındaki dava siyaseten Lütfi Fikri Bey’i bitirmiştir. Zira Tunaya'nın deyimiyle "acı bir muhakeme sonunda beraat ettiği zaman eski Lütfi Fikri Bey’den eser" 
kalmamıştır. ${ }^{70}$ Zaten bu davanın biraz da bu niyetle yapıldı̆̆ heyeti birçok defa günlüğündeki ifadeler geçmiş döneme ait olsa da kamuoyunun Lütfi Fikri'nin cumhuriyet hakkında ne düşündügünün bilinmesini istedikleri için günlüğü okuttuklarını söylemişlerdir. Diğer yandan Mahkeme Başkanı Ali Bey, Lütfi Fikri'nin abisi Münci Bey’in mektubu için "Mektup okunsun da beyefendilerin şahsiyetleri hakkında millet de tenevvür etsin" diyerek Lütfi Fikri’yi kamuoyu nazarında manen cezalandırmak istediğini açıkça belirtmiştir.

Gerçekten de Lütfi Fikri Bey beraatı sonrası mümkün olduğunca siyasetten uzak durmuş ve Galata'daki Yakut Han'da gerçek mesleği olan avukatlıkla uğraşmaya başlamıştır. Kansere yakalan Lütfi Fikri, tedavi olmak için gittiği Paris'te 7 Ekim 1934 tarihinde bağırsak kanserinden vefat etmiştir.

\section{KAYNAKÇA}

\section{Arşiv Vesikaları}

Başbakanlık Osmanlı Arşivi, Dahiliye Nezâreti Emniyet-i Umumiye Müdüriyeti Seyrü Sefer Kalemi, (DH. EUM. SSM), nu: 38/29

\section{Kitap, Makale ve Tezler}

Akbulut, Dursun Ali, Saltanat, Hilafet ve Millî Hâkimiyet, Samsun 1994.

Akcan, Erol, "Türkiye Cumhuriyeti’ni Laikleştiren İnkılapların Taşradaki Yansıması: "Hoca Askeri Olayı", Akademik Sosyal Araştırmalar Dergisi, Yı1: 5, Sayı: 59, Kasım 2017, s. 160176.

Aybars, Ergün, İstiklal Mahkemeleri, I-II, İzmir 1995.

Birinci, Ali, “Lutfi Fikri”, Diyanet Vakfi Íslam Ansiklopedisi, 2003.

Birinci, Ali, "Şerif Paşa, Mehmed”, İslam Ansiklopedisi, C: 39, Ankara 2010, s. 1-2.

Çulcu, Murat, Hilafetin Kaldırılması Sürecinde Cumhuriyetin İlanı ve Lütfi Fikri Davası, II, İstanbul 1992.

Demiraslan, Tekin, “1923 Milletvekili Seçimleri ve Basın”, Ahi Evran Üniversitesi Sosyal Bilimler Enstitüsü, Yayımlanmamış Yüksek Lisans Tezi, Kırşehir 2013.

Demirel, Ahmet, Birinci Mecliste Muhalefet, İstanbul 2007.

Esen, Nihal, “Şeyh Sait İsyanında Abdullah Sadi (Kör Sadi)'nin Faaliyetleri ve Yargılanması”, Fırat Üniversitesi Harput Uygulama ve Araştırma Merkezi Uluslararası Palu Sempozyumu Bildiriler Kitabı, s. 93-102.

\footnotetext{
70 Tarık Zafer Tunaya, "Muhalefet Tarihinin Heyecanlı Siması: Lütfi Fikri Bey", Insan Derisiyle Kaplı Anayasa, İstanbul 1988, s. 194.
} 
Gazel, Ahmet Ali, “II. Meşrutiyet Döneminde Projede Kalmış Bir Fırka Teşebbüsü: Müceddidin Firkas1," Tarih ve Toplum, 36/211, Temmuz 2001, 46-49.

Gazel, Ahmet Ali, “Lütfi Fikri Bey'in Ankara ile İstanbul'u Uzlaştırmak İddiasıyla 1920 Yılında Kurduğu Bir İttifak: Müsalemet İttifakı”. Mustafa Kemal Üniversitesi Sosyal Bilimler Enstitüsü Dergisi, 16/44, 2019, 14-44.

Gazel, Ahmet Ali, Lütfi Fikri'nin Tanzimat'l, Konya 2007.

Gazel, Ahmet Ali, Osmanlı Meclis-i Mebusan'ında Parlamenter Denetim, Konya 2007.

Istiklal Mahkemeleri-I, Ankara 2015.

Lütfi Fikri Bey’in Günlüğü, (Yayına Hazırlayan: Yücel Demirel), İstanbul 1991.

Lütfi Fikri, Hükümdarlık Karşısında Milliyet Mes'ûliyet ve Tefrîk-i Kuvâ Mesâili, İstanbul 1338.

Lütfi Fikri, Meşrutiyet ve Cumhuriyet, İstanbul 1339.

Mehmet Reşid, "Meşrutiyet Muhalefetinden Bir Safha Lütfi Fikri'nin Siyasi Mücadeleleri”, Dersim Mebusu Lütfi Fikri Bey’in Günlüğü, (Yayına Hazırlayan: Yücel Demirel), İstanbul 1991.

Riza Nur, Hayat ve Hatıratım, I, (Notlandıran ve Yayına Hazırlayan: Abdurrahman Dilipak), İstanbul 1991.

Simavi, Lütfi, Son Osmanlı Sarayında Gördüklerim, İstanbul 2004.

TBMM Zabut Ceridesi, Devre: 2, İçtima Senesi; 1, C: 5.

Tunaya, Tarik Zafer, "Muhalefet Tarihinin Heyecanlı Siması: Lütfi Fikri Bey”, Insan Derisiyle Kapli Anayasa, İstanbul 1988.

Tunaya, Tarık Zafer, “Türk Devrimine Karşı İdeolojik Bir Muhalefet Girişimi: "Tarikat-1 Salâhiyye Cemiyeti” ve Eylemleri”, IÜ. İktisat Fakültesi Mecmuası Özel Sayl, Cavit Orhan Tütengil'in Anisina Armă̆an, İstanbul, 1984, s.

Tunaya, Tarık Zafer, İslâmcılık Cereyanı, İstanbul 1962.

Tunaya, Tarık Zafer, Türkiye’de Siyasal Partiler, II, İstanbul1999.

Ülken, H. Ziya, Türkiye'de Çăgdaş Düşünce Tarihi, İstanbul 1992.

\section{Süreli Yayınlar}

Akşam

Cumhuriyet

Hakimiyet-i Milliye

İleri

Tanin

Tasvir-i Efkâr

Tazminat 